\title{
Trójmiejskie życie kulturalne w stanie wojennym i... „powojennym”
}

\begin{abstract}
Abstrakt: Artykuł obrazuje realia funkcjonowania ludzi kultury w Trójmieście po wprowadzeniu stanu wojennego. Zanalizowano codzienność twórczą aktorów, pisarzy, plastyków, fotografików, by móc odpowiedzieć na pytanie, czy stan wojenny wpływał na swobodę twórczą środowiska. Zestawiono działania oficjalnych instytucji ze zrodzonymi po ogłoszeniu stanu wojennego formami kultury niezależnej, która swobodnie działała dopiero w Kościele katolickim. Całość uzupełniono prezentacją konkretnych postaw ludzi, dla których stan wojenny wymusił nowy etap działania.
\end{abstract}

Słow a kluczowe: stan wojenny, artyści, kultura niezależna, Komitet Kultury Niezależnej, bojkot aktorski, Kościół katolicki.

Abstract: The article describes the reality of people of culture in the Tri-City after the imposition of martial law. It presents an analysis of everyday creativities of actors, writers, artists, and photographers, in order to answer the question whether the martial law in Poland influenced in any way the creative freedom of the community. It compares actions undertaken by official institutions with those forms of independent culture that developed under martial law only within the Catholic Church. This is supplemented with a presentation of individual people forced by martial law to enter a new stage of actions.

Keyw ords: martial law, artists, independent culture, Committee of Independent Culture, actors' boycott, Catholic Church.

Wprowadzenie w Polsce w grudniu 1981 r. stanu wojennego nie pozostało bez wpływu na ludzi kultury, gdyż zawieszenie pracy teatrów czy kin unieruchamiało artystów. Popularni od lat w Trójmieście aktorzy gdańskiego Teatru 
Wybrzeże, małżonkowie Halina Winiarska i Jerzy Kiszkis ${ }^{1}$, wspierający w sierpniu 1980 r. strajkujących robotników Stoczni Gdańskiej, 13 XII 1981 r. zostali internowani ${ }^{2}$. Ich koledzy z zespołu jeszcze tego samego dnia stawili się w pracy, mimo że wszyscy zostali bezterminowo urlopowani ${ }^{3}$, a część z nich natychmiast przystapiła do organizowania pomocy rodzinom nieobecnych, w tym nastoletniej córce Kiszkisów, pozostawionej samej w domu

Zamknięcie placówek i instytucji kultury wiązało się z ograniczeniem dostępu do oferty kulturalnej, tym bardziej że twórców z dnia na dzień pozbawiono możliwości wykonywania zawodu i zarobkowania. Środowisko gdańskich aktorów, tak jak wielu z całego kraju, dołączyło do bojkotu mediów, co było najbardziej zdecydowana reakcją ludzi kultury na wprowadzenie stanu wojennego. Jednoznaczne stanowisko „Solidarności”, wyrażone w komunikacie, jasno wskazywało, że „w środowisku aktorskim za kolaboranta uważany będzie każdy, kto występuje lub realizuje programy w radiu i telewizji (spektakle, audycje, słuchowiska) oraz uczestniczy w imprezach publicznych służących propagandzie reżimowej (akademie, rocznice, obchody świąt i uroczystości państwowych)" ". Każdy więc, kto łamał zasady tzw. kodeksu okupacyjnego i zdecydował się na współpracę z mediami, musiał się liczyć z odrzuceniem towarzyskim oraz wrogim nastawieniem publiczności, i nie były to wyłącznie deklaracje. Poparcie bojkotu uznawano za sprawę honorowa, a tych, którzy się z niego wyłamali, określano mianem zdrajców i łamistrajków. Ta spektakularna akcja, związana z przeciwstawieniem się działaniom władzy, była bardzo silnie nacechowana emocjonalnie ${ }^{6}$. Wszystkich oponentów usiłowano zdyskredytować, dlatego pojawiały się brutalne ataki na ludzi, którzy poparli bojkot, a zniknięcie znanych i lubianych twarzy z ekranu telewizji czy anteny

${ }^{1}$ Halina Winiarska w 1970 r. wcieliła się rolę Molly w spektaklu Ulisses Jamesa Joyce'a, reżyserowanym przez Zygmunta Hübnera, w przekładzie Macieja Słomczyńskiego. Spektakl ten stał się wydarzeniem sezonu teatralnego w Polsce i urósł do rangi najwybitniejszego przedstawienia Teatru Wybrzeża. Wielka kreacja aktorska Winiarskiej uznawana była za jej ogromny sukces i rolę życia. W 1971 r. Teatr Wybrzeże prezentował Ulissesa na Biennale Teatralnym w Wenecji i występował też dwukrotnie w Palazzo Grassi.

${ }^{2}$ Relacja Jerzego Kiszkisa z grudnia 2016 r., w zbiorach autorki. Aktor wspomniał, że już o godz. 5.00 rano, nie jak zwyczajowo o 6.00, czterech funkcjonariuszy zapukało do drzwi ich domu.

${ }^{3}$ Archiwum Państwowe w Gdańsku (dalej: AP Gdańsk), sygn. 1983, Wydział Pracy Ideowo-Wychowawczej. Protokoły Wojewódzkiego Sztabu Informacji i Propagandy, Notatka z posiedzenia Wojewódzkiego Sztabu Informacji i Propagandy 15 XII 1981 r., godz. 12.00, 1981-1983, k. 9.

${ }^{4}$ Relacja Elżbiety Goetel z grudnia 2016 r., w zbiorach autorki.

${ }^{5}$ Komunikat Solidarności Artystów Sceny i Filmu, „Wezwanie” 1982, nr 2, s. 130-131; A. Ruciński, Działalność Komitetu Kultury Niezależnej w latach 1982-1989, „Przegląd Prawniczy, Ekonomiczny i Społeczny” 2013, nr 4, s. 47-54, dostęp również: repozytorium. amu.edu.pl (pdf).

${ }^{6}$ Relacja Elżbiety Goetel z grudnia 2016 r., w zbiorach autorki. 
radiowej trudno było tłumaczyć inaczej niż pełnym odrzuceniem gotowości do legitymizowania poczynań Wojskowej Rady Ocalenia Narodowego (WRON). Protest artystów, jako bardzo widoczny i rozłożony w czasie sprzeciw, okazał się dotkliwy dla rządzących, a przecież jeszcze w latach siedemdziesiątych państwo chętnie widziało się w roli mecenasa sztuki i opiekuna gwiazd, z czego też wielu skwapliwie korzystało?

Bezradne wobec nieprzejednanej postawy artystów władze w ramach działań odwetowych rozwiązały Związek Artystów Scen Polskich oraz odwołały kilku opiniotwórczych dyrektorów teatrów. Bojkot trwał 320 dni i był nazywany najdłuższym strajkiem stanu wojennego, a zakończył się symbolicznie 26 IX 1983 r. telewizyjną emisja spektaklu pt. Pożadanie w cieniu wiqzów Eugene’a O’Neilla, w reżyserii Grzegorza Skurskiego, z udziałem m.in. Krystyny Jandy, Jerzego Bińczyckiego i Bogusława Lindy. Niektórzy, jak Tadeusz Łomnicki, nie zdecydowali się na podjęcie współpracy z telewizja aż do 1989 r. ${ }^{8}$

Aktorki Teatru Wybrzeże Halina Słojewska-Kołodziej i Elżbieta Goetel również poparły bojkot, a z grupa pozostałych kolegów zaangażowały się $\mathrm{w}$ akcję niesienia pomocy materialnej i prawnej rodzinom represjonowanych, realizowanej w ramach Komitetu Pomocy Internowanym i Aresztowanym. Rozwoziły paczki. Goetel wykonywała to zadanie w robotniczej dzielnicy Gdańska Dolne Miasto, co - jak wspominała - wcale nie było łatwe, gdyż odwiedzając osoby często wcześniej wyrzucone z pracy, musiała najpierw przekonać ich do siebie, wzbudzić zaufanie i uzasadnić, dlaczego młoda kobieta nagle przychodzi do obcego domu z pomoca ${ }^{9}$.

Całkowitą blokadę i odcięcie społeczeństwa od dostępu do kultury natychmiast zagospodarował Kościół, który oferował przestrzeń na potrzeby wolnościowej twórczości realizowanej pod szyldem Komitetu Kultury Niezależnej (KKN), powołanego w styczniu 1982 r. w Warszawie. Komitet wspierał wystawy plastyczne, prezentacje teatralne, inicjatywy artystów mające na celu swobodny obieg sztuki, niezależne konkursy, spotkania twórców, działalność wydawniczą i naukową. Wydawał też miesięcznik „Przedświt”, rekomendujący różne wydarzenia kulturalne, w tym wystawy plastyczne i inne akcje organizowane wspólnie z Kościołem katolickim. W marcu 1983 r. rozpoczął drukowanie „Kultury Niezależnej” - ogólnopolskiego miesięcznika informującego o podziemnej działalności kulturalnej i zamieszczającego teksty literackie, wiersze, prozę, eseje literackie i historyczne, recenzje, artykuły oraz wywiady z twórcami związanymi z opozycją podziemna, jak również komunikaty KKN, zawiadomienia o corocznych nagrodach kulturalnych

\footnotetext{
${ }^{7}$ M. Luxenberg-Łukowska, Bojkot mediów w stanie wojennym, http://dzieje.pl/artykuly-historyczne/bojkot-mediow-w-stanie-wojennym (dostęp: 13 I 2017).

${ }^{8}$ D. Przastek, Środowisko teatru w okresie stanu wojennego, Warszawa 2005.

${ }^{9}$ Relacja Elżbiety Goetel z grudnia 2016 r., w zbiorach autorki.
} 
„Solidarności” czy notki w rubrykach „Kronika życia kulturalnego w PRL” oraz „Wydarzenia”, prezentujące recenzje i szkice teatralne ${ }^{10}$.

Dzięki powstaniu Komitetu po wprowadzeniu w Polsce stanu wojennego mogła się rozwijać podziemna, niezależna od władz państwowych, kultura i sztuka, a twórcy działający przy dziesiątkach duszpasterstw akademickich, funkcjonujących w okresie legalnej „Solidarności”, które nie zostały rozwiązane, zdobywali uznanie i nagrody oraz wzmacniali podziemne struktury, nadając im jednocześnie nowy wymiar aktywności, przez co w naturalny sposób przekształcały się one w enklawy wolnej myśli ${ }^{11}$. Pomagano internowanym i ich rodzinom, wspierano na duchu przestraszonych ludzi. Bez Kościoła, który stał się fundamentem działania i dawał schronienie, a także przestrzeń dla twórczości artystycznej, nie odbyłoby się wiele wieczorów poetyckich, inscenizacji teatralnych, wystaw, pokazów filmowych, koncertów, wykładów naukowych i dyskusji, gdyż stan wojenny spowodował zarazem naturalny zwrot w kierunku kultury katolickiej ${ }^{12}$. Kościół niejako wykorzystał niszę, jaką tworzyły zamknięte sale koncertowe, teatry, redakcje i wydawnictwa. Ludzie kultury przyłączali się do organizowania życia kulturalnego w świątyniach, dzięki czemu wypełnili powstała pustkę nową oferta, pozwalająca ludziom oderwać się od opresyjnej rzeczywistości, i w ten sposób budowali wspólnotę odbiorców nowych form artystycznych ${ }^{13}$. Bardzo szybko docierali tam liczni aktorzy, literaci, plastycy, naukowcy; również gdańskie aktorki od razu aktywnie zaangażowały się $\mathrm{w}$ regularnie organizowane msze za ojczyznę w kościele św. Mikołaja w Gdańsku, wieczory poezji patriotyczno-maryjnej w bazylice Mariackiej oraz w tygodnie kultury chrześcijańskiej przygotowywane w kościele oo. Jezuitów we Wrzeszczu. Tym działaniom każdorazowo przyświecało inne hasło. Podczas takich spotkań niejednokrotnie czytano poezję religijno-patriotyczną oraz niezwykle wówczas aktualne klasyczne teksty.

Twórczość młodych spędzających wiele czasu w kościołach nie pozostała bez wpływu na samych artystów, czego przykładem była sztuka nacechowana sacrum, w tym popularne wtedy artystyczne szopki bożonarodzeniowe i wielkanocne groby Pańskie, zawierające elementy nietypowej codzienności panujacej w kraju. Pojawiały się więc w tych kościelnych prezentacjach

${ }^{10} \mathrm{~W}$ prace KKN byli zaangażowani tacy twórcy, jak Kazimierz Orłoś, Tadeusz Kaczyński, Krzysztof Knittel, Kazimierz Kaczor, a także m.in. krytycy Marta Fik, Andrzej Osęka i Aleksander Wojciechowski.

${ }^{11}$ E. Małachowska, Duszpasterstwa akademickie a kultura niezależna $w$ Kościele $w$ latach osiemdziesiatych, ze szczególnym uwzględnieniem Górnego Ślaska, „Biuletyn IPN” 2011, nr 1-2, s. 57.

12 Mateusz Wyrwich, autor trzech tomów reportaży o niezwykłych księżach, dotarł do 200 kapelanów „Solidarności” (idem, Kapelani Solidarności 1980-1989, t. I-III, Warszawa 2005- 2009).

${ }^{13}$ S. Ligarski, T. Ruzikowski, Kultura niezależna, w: Pokolenie '80. Niezależna twórczość młodych w latach 1980-1989, red. T. Boruta, Kraków 2010, s. 69-77. 
kraty, pałki, kajdany, paczki i postacie milicjantów, w czym zawarty był protest przeciwko dyktaturze Wojciecha Jaruzelskiego. Skala zaangażowania środowiska twórców w podziemną działalność artystyczną okazała się znacząca, gdyż wielu z nich doskonaliło swoje umiejętności właśnie w tej formie wypowiedzi ${ }^{14}$. Plastyczne w obrazie, ale kontrowersyjne w treści dekoracje Grobu Pańskiego występowały jeszcze w latach dziewięćdziesiątych w kościele św. Brygidy u kapelana „Solidarności” ks. Henryka Jankowskiego ${ }^{15}$. Mimo istniejących różnic ideowych Kościół skupiał ludzi na zasadzie wspólnoty, a nie przeciagania na swoją stronę, nie wykorzystywał silnej pozycji, jaką zbudował, dlatego dla wielu stał się autentyczną inspiracją i wolną przestrzenia do prowadzenia dialogu społecznego ${ }^{16}$.

Z końcem stycznia 1982 r. stopniowo przywracano działalność trójmiejskich instytucji kultury, najszybciej teatrów i kin z repertuarem dziecięcym, choć i on był poddawany kontroli ${ }^{17}$. Teatr Miniatura w styczniowym repertuarze prezentował Koziotka Matołka oraz Robin Hooda, Teatr Dramatyczny w Gdyni - Krasnoludki, krasnoludki Tadeusza Kijonki, Króla Jelenia II Bohdana Korzeniewskiego, Konkurs stulecia Stephena Poliakoffa oraz Tato, tato sprawa się rypła Ryszarda Latki ${ }^{18}$. Teatr Muzyczny wznowił działalność bajka $W$ zielonej krainie OZ oraz operetka Piraci. Filharmonia Bałtycka pierwsze koncerty dała 15 i 16 I 1982 r. symfonia Piotra Czajkowskiego i uwertura do opery Wolfganga Amadeusza Mozarta Don Juan. Teatr Wybrzeże wystawiał, zawieszone w grudniu, Betlejem polskie Lucjana Rydla w reżyserii cenionego Marcela Kochańczyka ${ }^{19}$. Sztuka została pomyślana jako szopka bożonarodzeniowa, ale po 13 grudnia nabrała nowej wymowy, chociaż nie zmieniono w jej tekście ani jednego zdania. Odbiór przez widownię okazywał się za każdym razem niezwykle entuzjastyczny, a przedstawienia przeradzały się w swego

14 T. Boruta, Pokolenie '80. Niezależne malarstwo młodych w wystawienniczym ruchu przykościelnym, „Biuletyn IPN” 2011, nr 1-2, s. 29-38.

${ }^{15}$ W 1995 r. wystrój Grobu Pańskiego wywoływał oburzenie, gdyż na czerwonym płótnie umieszczono znak swastyki, sierpa i młota, gwiazdę Dawida oraz napisy: „NSDAP”, „SS”, „NKWD”, „KGB” „UB” i „SB”. Obok znajdowały się skróty nazw partii: „PSL”, „SLD”, „UW”, „UP”, a także „PZPR”. Cztery lata później dekoracja nawiązywała do akcji obrony krzyża na żwirowisku w Oświęcimiu, prowadzonej przez Kazimierza Świtonia. W 2001 r. wielkanocny przekaz ks. Jankowskiego przedstawiał miniaturę zwęglonej stodoły w Jedwabnem z ludzkim szkieletem, z napisem: „Żydzi zabili Pana Jezusa i Proroków i nas także prześladowali”. Metropolita gdański abp Tadeusz Gocłowski nakazał usunięcie napisu. W 2004 r. dekoracja ks. Jankowskiego skierowana była przeciwko Unii Europejskiej.

16 A. Wysocka, Kultura w czasach zniewolenia, „Idziemy” 2009, nr 50 (223), s. 14-17.

17 AP Gdańsk, sygn. 937, XVI Zwyczajna sesja WRN 1983, Sejmowa Komisja Kultury 1983-1989, Uchwały WRN 1982, Tezy do opracowania „Warunki rozwoju kultury w woj. gdańskim, Gdańsk, 14 X 1982 r., k. 38-39.

18 AP Gdańsk, KW PZPR, sygn. 1983, Wydział Pracy Ideowo-Wychowawczej. Protokoły Wojewódzkiego Sztabu Informacji i Propagandy, Ustalenia z posiedzenia Wojewódzkiego Sztabu Informacji i Propagandy z 5 I 1982 r., 1981-1983, k. 31.

19 „Dziennik Bałtycki”, „Głos Wybrzeża”, „Wieczór Wybrzeża”, 13 I 1982, s. 2. 
rodzaju manifestacje ${ }^{20}$. Zespół teatru był całkowicie zaskoczony zaistniałym zjawiskiem - gdy tylko aktorzy pojawiali się na scenie, czuło się niewidzialną płaszczyznę porozumienia z odbiorcami spektaklu. Rola Heroda w wykonaniu aktora Piotra Suchory jednoznacznie nasuwała skojarzenia z Jaruzelskim, co wywoływało aplauz i ogromne brawa, gdyż ludzie byli szczególnie wyczuleni na wszelkie aluzje ${ }^{21}$. Z kolei wers kolędy Dzisiaj w Betlejem stał się swoistym manifestem dla wszystkich obecnych w teatrze, publiczność wiwatowała na stojąco, a przed żłóbkiem składano petycje. Jak podkreślała Goetel, aktorzy nie kłaniali się po spektaklu, zapadała cisza, na scenie jakby wszystko zamierało. Kurtyna opadała wówczas w dół i podnosiła się w górę, aktorzy stali, publiczność krzyczała, co sprawiało niesamowite wrażenie. Społeczeństwo wyrażało w ten sposób aprobatę i podziękowanie za postawę aktorów w okresie stanu wojennego, tj. przystapienie do bojkotu. Goetel wspominała to z nostalgia: „nigdy nas nie kochali tak, jak w tamtym okresie”22. Cenzura usunęła z tego tekstu fragment modlitwy Matki Boskiej, gdyż jak uzasadniano, „mógłby on naruszać uczucia osób niewierzących”, oraz wiersza powstańca z 1863 r., by nie wpływał na „nadmiernie religijny nastrój” ${ }^{23}$.

Winiarska i Kiszkis wrócili z internowania do domu i szczęśliwie mogli kontynuować pracę $\mathrm{w}$ dotychczasowym zespole, co nie było wcale oczywiste, ale jak podkreślał uznany aktor, dyrekcja potraktowała ich po przyjacielsku ${ }^{24}$. Terminy rozpoczęcia działalności teatrów zależały od zweryfikowania przez władze repertuaru poszczególnych scen pod kątem przedstawianych w nich treści. Część aktorów była ponadto angażowana w organizowanie imprez dla żołnierzy, szczególnie w czasie świąt ${ }^{25}$.

Teatr Wybrzeże w sezonie 1982-1983 wystawił dziewięć premier. Na afiszach znalazły się dzieła klasyczne, takie jak Kordian Juliusza Słowackiego, Pan Damazy Józefa Blizińskiego i Grzesznicy bez winy Aleksandra Ostrowskiego. Ze współczesnego repertuaru grano cztery sztuki polskie i jedną węgierska. Młodym widzom zaproponowano spektakl pt. $O$ dwóch takich, co ukradli księżyc Kornela Makuszyńskiego, cieszący się dużym powodzeniem. Najbardziej udane okazały się inscenizacja Kordiana oraz przedstawienie dla dzieci, ale za porażkę uznano Reportaż $z$ pop-festiwalu

${ }^{20}$ E. Szczesiak, My, podziemni. Cisi bohaterowie stanu wojennego, Gdańsk 2006, s. 85-91; Relacja Elżbiety Goetel z grudnia 2016 r., w zbiorach autorki.

${ }^{21}$ Relacja Jerzego Kiszkisa z grudnia 2016 r., w zbiorach autorki.

${ }^{22}$ Relacja Elżbiety Goetel z grudnia 2016 r., w zbiorach autorki.

${ }^{23}$ Teatr drugiego obiegu. Materiaty do kroniki teatru wojennego 13 XII 1981 - 15 XI 1989, oprac. i red. J. Krakowska-Narożniak, M. Waszkiel, Warszawa 2000, s. 29.

${ }^{24}$ Relacja Haliny Winiarskiej i Jerzego Kiszkisa z grudnia 2016 r., w zbiorach autorki; Relacja Igora Michalskiego z listopada 2016 r., w zbiorach autorki.

25 AP Gdańsk, sygn. 1983, Wydział Pracy Ideowo-Wychowawczej. Protokoły Wojewódzkiego Sztabu Informacji i Propagandy, Notatka z posiedzenia Wojewódzkiego Sztabu Informacji i Propagandy 20 XII 1981 r., godz. 12.00, 1981-1983, k. 21. 
Tibora Déryego i Biuro pisania podań Władysława Terleckiego. Gdy marcu 1982 r. wojewoda gdański wręczał doroczne nagrody teatralne, wśród laureatów znaleźli się także aktorzy Teatru Wybrzeże, w tym Henryk Bista, Anna Chodakowska, Jerzy Łapiński i Barbara Patorska. Większość teatrów nie stworzyła nowego repertuaru dla dzieci, a w Wybrzeżu od 10 lat można było oglądać spektakl Zbigniewa Żakiewicza Kraina sto piatej tajemnicy, w Teatrze Dramatycznym - Anię z Zielonego Wzgórza, wspomniane już Krasnoludki, krasnoludki, ponadto Wielka tajemnice, w Teatrze Miniatura - Turonia, Diabelskie skrzypce, Wyspe wierszy pana Tuwima. W kwietniu 1982 r. podczas narady dyrektorów placówek kultury z udziałem władz wojewódzkich za dyskusyjną uznano jedynie obecność w repertuarze sztuk - jak je nazwano - katolickich: Betlejem polskie i Hiob, które ostatecznie zostały wykreślone z programu ${ }^{26}$.

W Teatrze Wybrzeże nie występowało zjawisko spontanicznej akcji wyklaskiwania czy wykasływania aktorów, do czego dochodziło w innych placówkach teatralnych w kraju. Stanowiło to formę kary dla tych, którzy poparli stan wojenny i nie przystapili do bojkotu. Najbardziej znanym przypadkiem był incydent związany z ulubieńcem ekranu Stanisławem Mikulskim. Gdy w czasie spektaklu w Teatrze Polskim Sto rak, sto sztyletów aktor miał wygłosić swoja kwestię, ludzie zaczęli kaszleć tak, że jego głos toną w hałasie. Innym razem Janusz Kłosiński w Teatrze Narodowym w Warszawie został wygwizdany za wcześniejszy swój występ w „Dzienniku Telewizyjnym”. Bardzo popularny dotąd aktor zapłacił za to depresją i jak wspominała Zofia Kucówna, „skończył się zawodowo”27. Gdańscy aktorzy Teatru Wybrzeże czuli sympatię i wsparcie widowni, czego odzwierciedleniem był też zawsze wypełniony po brzegi teatr ${ }^{28}$.

$\mathrm{Z}$ biegiem kolejnych tygodni, gdy z ramówki telewizyjnej znikały popularne nazwiska, pełen rozkwit przeżywał teatr, z tym że ten niezależny, podziemny. Środowisko aktorskie, zmuszone do poszukiwania nowych form kontaktu $\mathrm{z}$ widzem, w momencie gdy droga do telewizji została zamknięta dla wszystkich negujących stan wojenny, uaktywniło się w innej przestrzeni. Teatr funkcjonował w dwóch odsłonach: jako domowy, „ściśle tajny” oraz kościelny, jawny i dostępny dla szerszej publiczności, używany jako pewnego rodzaju forma walki bez przemocy. Niezależny teatr był obecny w każdej części kraju, zarówno w dużych, miejskich ośrodkach, jak i w najmniejszych parafiach. Początkowo dominował w nim repertuar obejmujacy lektury szkolne, ale z czasem wpisywał się w kontekst miejsca, nastrój i klimat dni stanu

\footnotetext{
${ }^{26}$ AP Gdańsk, KW PZPR, sygn. 1975, Wydział Pracy Ideowo-Wychowawczej. Dokumenty Komisji Kultury KW PZPR, Sytuacja społeczno-polityczna w Teatrze Wybrzeże, 25 I 1985 r., k. $14-23$.

${ }_{27}$ Celebryci w stanie wojennym. Komedianci strajkuja, http://www.styl.pl/magazyn/news-celebryci-w-stanie-wojennym-komedianci-strajkuja,nId,2147269 (dostęp: 15 III 2016).

${ }^{28}$ Relacja Elżbiety Goetel z grudnia 2016 r., w zbiorach autorki.
} 
wojennego, współgrał z oczekiwaniami odbiorców oraz budował szczególny rodzaj wspólnoty i protestu wobec ówczesnej sytuacji społeczno-politycznej ${ }^{29}$.

W niezależnym życiu teatralnym lat osiemdziesiątych rzeczywistość polityczna głęboko mieszała się ze sztuka, a nawet odgrywała w niej kluczowa rolę, gdyż artyści - często w odpowiedzi na represje - wystawiali sztuki objęte zakazem i zapisem cenzury. Przedstawienia organizowano w domach aktorów lub osób związanych ze środowiskiem teatralnym, co właśnie składało się na popularny teatr domowy, gdzie czytano m.in. utwory Adama Mickiewicza, Juliusza Słowackiego, Stanisława Wyspiańskiego czy śpiewano pieśni ${ }^{30}$. Teatr domowy działał do końca lat osiemdziesiąych i był niezależna forma wypowiedzi artystycznej oraz odpowiedzia na lubiane dotąd poniedziałkowe spektakle Teatru Telewizji, nadawane w TVP 1. Artyści teatru domowego solidaryzowali się z internowanymi i represjonowanymi kolegami, często im właśnie dedykowali występy oraz organizowali zbiórki pieniędzy dla ich rodzin. Twórczość prezentowana w prywatnych mieszkaniach i kościołach stała się symbolem walki artystów z reżimem komunistycznym o wolność słowa oraz niezależność w życiu kulturalnym. Teatr domowy czerpał ze wzorców okupacyjnych i przeznaczony był dla zamkniętego grona zaufanych odbiorów, toteż informacje o kolejnych spektaklach rozchodziły się „poczta pantoflową"31. Jako odpowiedź na stan wojenny i zniewolenie stał się prawdziwym wyzwaniem dla artystów, choćby ze względu na warunki, w jakich przyszło im grać, często w ograniczonej powierzchni mieszkań, przy świecach lub świetle latarek zamiast reflektorów, bez przestrzennego dystansu między sceną a widownia, bo publiczność pojawiała się pod nogami, z reguły zasiadała na podłodze, a tylko nieliczni na kanapach i krzesłach ${ }^{32}$. Podobnie sytuacja wyglądała z bardzo popularnymi w PRL kabaretami, w części tolerowanymi przez władzę, choć padały w nich słowa niewypowiadane przez żadne media. Jak podkreślał Krzysztof Skiba, członek licealnego kabaretu „Błazenada 81”, którego spektakl odbywał się w Gdańsku 12 XII 1981 r., a został przerwany wprowadzeniem stanu wojennego, zanim to nastapiło, ludzie byli szczególnie wyczuleni na wszelkie aluzje, czytali między wierszami i czasem wystarczyło

${ }^{29}$ D. Przastek, Scena bez ktamstw. Teatr w kościele po 13 grudnia 1981 roku, „Biuletyn IPN" 2011, nr 1-2, s. 48.

30 T. Kozłowski, Aktorski bojkot, „Rzeczpospolita”, 13 XII 2011, s. 6; Relacja Elżbiety Goetel z grudnia 2016 r., w zbiorach autorki.

${ }^{31}$ W Warszawie po raz pierwszy Teatr Domowy zagrał 1 XI 1982 r., w mieszkaniu Ewy Dałkowskiej, sztukę w reżyserii Elżbiety Bukowińskiej Przywracanie porzadku, przygotowaną na podstawie widowiska poetyckiego zdjętego ze sceny w Teatrze Powszechnym. Pierwszy spektakl obejrzało 40 widzów, w sumie sztukę wystawiono ok. 100 razy i widziało ją łącznie ok. 5 tys. osób.

${ }^{32}$ M. Cedro, 30 lat temu - w stanie wojennym - Teatr Domowy zagrat pierwszy spektakl, http://dzieje.pl/kultura-i-sztuka/30-lat-temu-w-stanie-wojennym-teatr-domowy-zagral-pierwszy-spektakl (dostęp: 31 X 2017). 
hasło, by wywołać aplauz ${ }^{33}$. Stan wojenny zmienił formułę żartów, przestały być one lekkie i przyjemne, mające omijać tylko cenzurę, zaczęto już mówić wprost o zdrajcach narodu i złych rządzących.

Inną bardzo ważną przestrzenią dla niezależnego teatru stały się kościoły, w których można było prezentować wolnościowe myśli społeczno-polityczne i swobodnie się wypowiadać. W gdańskim kościele Pallotynów przy Akademii Medycznej wystawiano Wieczernik Ernesta Brylla. Kościół ten otoczony był zielenia, która przedostawała się do wnętrza przez okna za ołtarzem, co tworzyło naturalna, unikatowa scenografię, współgrająca ze skromną kolacja, na której oferowano tylko suche bułki i lampkę wina. To wszystko wzmacniało przekaz i sprawiało wyjątkowe wrażenie ${ }^{34}$. Kiedy w dolnym kościele Najświętszej Maryi Panny Królowej Różańca Świętego na Przymorzu, w tzw. okraglaku, nieoficjalnym ośrodku kultury niezależnej w latach siedemdziesiątych i osiemdziesiątych, wystawiano tę sztukę, grę aktorów zakłócały wyjące syreny radiowozów, które nagle pojawiały się przed kościołem. To znów paradoksalnie korespondowało z wypowiadanymi tekstami, szczególnie gdy była mowa o lęku apostołów zamkniętych w wieczerniku ${ }^{35}$. Spektakl w reżyserii Słojewskiej-Kołodziej grano kilkakrotnie w różnych świątyniach Gdańska i Warszawy ${ }^{36}$. Innym razem, już w 1984 r., gdy w kościele św. Brygidy prezentowano sztukę Bolesława Faca Czuwanie: rapsod wielkopostny, tekst współbrzmiał z nastrojami patriotyczno-religijnymi. U oo. jezuitów swoją premierę miał również spektakl The Cocktail Party Thomasa S. Eliota, w reżyserii Ireny i Tadeusza Byrskich ${ }^{37}$.

Oprócz spektakli teatralnych ważną rolę odgrywały wieczory poezji, podczas których czytano wiersze Zbigniewa Herberta czy biblijne Treny Jeremiasza w tłumaczeniu Czesława Miłosza, przy akompaniamencie wiolonczeli, a także równie nastrojowe msze za ojczyznę, celebrowane regularnie raz w miesiącu u gdańskich dominikanów. Te niezwykle emocjonalne nabożeństwa podnosiły na duchu oraz budowały klimat solidarności i jedności, a uczestniczyli w nich ci sami ludzie, którzy w sierpniu 1980 r. występowali w Stoczni Gdańskiej. W rzeczywistości stanu wojennego nawet klasyczne teksty, napisane sto lat wcześniej, okazywały się niezwykle aktualne, trafne i nieprzewidywalne w swej wymowie. Odzew na hasło mszy patriotycznej był nadspodziewanie duży, bowiem do kościoła św. Mikołaja w Gdańsku docierali ludzie z miejscowości

${ }^{33}$ Relacja Krzysztofa Skiby z maja 2017 r., w zbiorach autorki.

${ }^{34}$ Relacja Haliny Winiarskiej i Jerzego Kiszkisa z grudnia 2016 r., w zbiorach autorki.

35 Ibidem.

${ }^{36}$ AP Gdańsk, KW PZPR, 1975, Wydział Pracy Ideowo-Wychowawczej. Dokumenty Komisji Kultury KW PZPR 1983-1985, Stanowisko Wydziału Ideologicznego i Informacji KW PZPR w Gdańsku w sprawie oceny sytuacji społeczno-politycznej w Teatrze Wybrzeże, 27 I 1986 r., k. nlb.

${ }^{37}$ Relacja Elżbiety Goetel z grudnia 2016 r., w zbiorach autorki; Relacja Jerzego Kiszkisa z grudnia 2016 r., w zbiorach autorki. 
przyległych do Trójmiasta ${ }^{38}$. Zawsze przejmujące były też słowa wykonywanej pieśni Boże, coś Polskę w wersji „ojczyznę wolna racz nam wrócić, Panie”39. W każdym tygodniu odbywały się różnego rodzaju spotkania modlitewne i biblijne, a nasycenie indywidualności w jednym miejscu owocowało pięknymi w formie nabożeństwami odprawianymi w intencji ojczyzny, których nie zaprzestano aż do 1989 r. W mszach za ojczyznę u gdańskich dominikanów brali udział m.in.: Teresa Ferenc, Goetel, Gustaw Holoubek, Zbigniew Jankowski, Kiszkis, Anna Nehrebecka, Władysław Przybylski, Hanna Skarżanka, Halina Łojewska i Winiarska ${ }^{40}$.

Rozkwit kultury niezależnej w Kościele nie byłby możliwy bez wyjątkowych i odważnych ludzi, jak dominikanin o. Sławomir Słoma, przychylny opozycji i do dziś wspominany w Gdańsku z wdzięcznościa, przede wszystkim dlatego że przygarniał każdego, kto szukał pomocy. Jak podkreślaja po latach ci, którym jej udzielał, ujmował otwartościa, tolerancją i tym, że rozumiał problemy zwykłych ludzi. Ojciec Słoma już w grudniu 1981 r. podczas demonstracji w pobliżu pomnika Poległych Stoczniowców, bezpośrednio na środku ulicy, naprzeciwko zomowców, odprawił mszę „na dłoniach”41. Innym razem, po 30 I 1982 r. i ogłoszonym przez Ronalda Reagana Dniu Solidarności z Polska, gdy tylko dowiedział się o zatrzymanych studentach, bezzwłocznie, nieproszony przez nikogo, szukał ich i wyciagał z komisariatów ${ }^{42}$. Dzięki niemu bazylika św. Mikołaja stała się w stanie wojennym dla wielu środowisk azylem, a on sam był mentorem młodych, którym udostępniał przestrzeń do działania. Ojciec Słoma za swoją postawę zapłacił wysoką cenę, mimo protestów gdańszczan w 1985 r. musiał na zawsze opuścić miasto, z czym chyba nie pogodził się do dzisiaj ${ }^{43}$.

Skupieni wokół o. Słomy trójmiejscy plastycy tworzyli środowisko przyszłej Galerii św. Jacka, on sam zainicjował Duszpasterstwo Środowisk Twórczych Wybrzeża oraz wydawał pismo „Dołek”, rozprowadzane podczas niedzielnych mszy św. Pod patronatem „Górki” - tak nazywano lokal w klasztorze na piętrze, gdzie mieściło się duszpasterstwo akademickie założone przez zasłużonego już duszpasterza o. Ludwika Wiśniewskiego, który towarzyszył

${ }^{38}$ Relacja Elżbiety Goetel z grudnia 2016 r., w zbiorach autorki; Relacja Jerzego Kiszkisa z grudnia 2016 r., w zbiorach autorki.

39 Archiwum Państwowe w Gdyni, KM PZPR, 358, Informacje KM PZPR do KW PZPR w Gdańsku, Telefax z 18 II 1982 r., k. nlb.

${ }^{40}$ M. Grubka OP, Działania władz państwowych i kościelnych wobec gdańskiego duszpasterza akademickiego o. Stawomira Stomy OP (1979-1985), w: Komunistyczny aparat represji wobec Polskiej Prowincji Dominikanów, red. M. Miławicki OP, M. Wenklar, Kraków 2015, s. $270-288$.

${ }^{41}$ Odbyło się to przed wejściem do Biblioteki PAN, za ołtarz służył plecak położony na dłoniach uczestników, a msza była celebrowana podczas trwającej demonstracji.

${ }^{42}$ Relacja Leszka Biernackiego z lutego 2017 r., w zbiorach autorki; Relacja Jerzego Kiszkisa z grudnia 2016 r., w zbiorach autorki.

${ }^{43}$ Relacja o. Sławomira Słomy z lutego 2017 r., w zbiorach autorki. 
kilku pokoleniom wychowanków, w tym działaczy społecznych i politycznych ${ }^{44}$ - odbywały się ważne spotkania, a w parafii toczyło niezależne życie intelektualne. Pierwsi na „Górce” pojawili się poeci, którzy utworzyli Akademicki Krag Literacki „Górka”, a po 1982 r. przyjęli nazwę „Wiązania”. Z czasem dołączyli do nich plastycy z gdańskiej Akademii Sztuk Pięknych, nieco później dziennikarze z zawieszonych bądź zlikwidowanych redakcji. Na istniejącej wewnątrz świątyni tablicy informacyjnej, zwanej „Maciejka”, w nawiązaniu do Macieja Szczepańskiego, wieloletniego przewodniczącego Komitetu ds. Radia i Telewizji, redagowano gazetkę ścienna pt. „Skarbczyk Dominikański”. Jej autorami byli Izabella Greczanik-Filipp, Alicja Balińska i Andrzej Drzycimski. Istniały również tzw. gazeta mówiona i punkty mówione autorstwa Pawła Huellego, odczytywane w pierwszy piątek miesiąca ${ }^{45}$. W kościele organizowano prelekcje, wykłady, spotkania z artystami, sympozja, takie jak „Wezwanie do obecności” czy „Sztuka a sumienie”. Tam też regularnie aż do 1989 r. działało powołane przez Macieja Łopińskiego Duszpasterstwo Dziennikarzy ${ }^{46}$. Na wieczorach autorskich, organizowanych przez gdańskich pisarzy, występowali: Stanisław Dąbrowski, Stanisław Esden-Tempski, Fac, Ferenc, Aleksander Jurewicz, Kazimierz Nowosielski, Bożena Ptak, Edmund Puzdrowski, Zbigniew Szymański, Janina Wieczerska, Władysław Zawistowski, Żakiewicz, a także osoby spoza Trójmiasta: Tomasz Burek, Julia Hartwig, Erwin Kruk, Ryszard Krynicki, Artur Międzyrzecki, Jan Józef Szczepański, Wiktor Woroszylski i inni. W zielonej sali na „Górce” w 1984 r. Drzycimski i Adam Kinaszewski, pod wspólnym pseudonimem Jan Mur, napisali Dziennik internowanego oraz zredagowali autobiografię Lecha Wałęsy Droga nadziei ${ }^{47}$.

Środowisko artystów plastyków skupiała Galeria św. Jacka, ponieważ oni sami byli pozbawieni możliwości wolnego wypowiadania się, a nie chcieli uczestniczyć w reżimowym życiu artystycznym. Galeria św. Jacka rozwinęła się w swoisty fenomen, gdyż każdą wystawę w niej prezentowaną odwiedzały tłumy, była miejscem swobody twórczej, innej niż ta oficjalna, stała się przestrzenią wolności i radości ${ }^{48}$. W krypcie kościoła funkcjonowała również księgarnia, w której Barbara Madajczyk sprzedawała wydawnictwa oficyny W Drodze. To ona sprawowała początkowo opiekę nad galeria, później zajmowali się nią Edmund Krasowski oraz Alina Afanasjew, Krystyna Frezer i Jan Góra. Równolegle schronieniem dla plastyków był kościół św. Michała w Sopocie, w którym również odnajdywano wolną przestrzeń dla sztuki

${ }^{44}$ P. Zaremba, Młodopolacy. Historia Ruchu Młodej Polski, Gdańsk 2000.

${ }^{45}$ Relacja Pawła Huellego z kwietnia 2017 r., w zbiorach autorki.

${ }^{46}$ Relacja Macieja Łopińskiego z czerwca 2012 r., w zbiorach autorki.

${ }^{47}$ M. Grubka, Stawek - duszpasterz studentów i artystów, fragmenty niepublikowanej pracy doktorskiej, 2006, w: Niepokora. Artyści i naukowcy o Solidarności 1980-1989, red. S. Figlarowicz i in., Gdańsk 2006, s. 41-44.

${ }^{48}$ H. Solway, Przestrzeń wolności, fragmenty rozmowy z Elżbieta Trybus, Gdańsk, sierpień 2006, w: Niepokora..., s. 115-116. 
i nieocenzurowanej twórczości. Wyrażanie nastrojów/ komentowanie rzeczywistości poprzez sztukę umożliwił świeżo wyświęcony ks. Krzysztof Niedałtowski, obecnie duszpasterz środowisk twórczych archidiecezji gdańskiej ${ }^{49}$. Wielkim sukcesem okazała się prezentowana w salkach katechetycznych wystawa pt. „Walizka warszawska”. Pomysł opierał się na przygotowaniu przez cenionych artystów z Warszawy prac w formacie, który zmieści się do walizki, by można je było dalej swobodnie przewozić i prezentować w całym kraju. Wystawy w Galerii św. Michała w Sopocie organizowano regularnie, a ich animatorami byli Jan i Barbara Górowie, A. Afanasjew, Maria Kuczyńska i Maria Targońska. Twórcy chętni do wzięcia udziału w projekcie mogli deklarować swoją obecność spontanicznie, gdyż wystawy nie miały kuratora, a prace katalogowano w najprostszy sposób, przy czym znakiem identyfikacyjnym było logo z uskrzydlonym krzyżem, zaprojektowane przez Janusza Osickiego. Instalowano je w soboty w salkach katechetycznych w dolnym kościele, zaraz potem - w sobotnie lub niedzielne wieczory - odbywał się wernisaż, a w poniedziałki rano wszystko wracało na miejsce, by wieczorem młodzież mogła znów się uczyć katechezy. Wystawy spotykały się z fenomenalnym odbiorem, gdyż po mszach św. docierały tłumy ludzi, by oglądać najczęściej mało zrozumiała sztukę współczesna, wtedy jednak odczytywana jako sztuka niezgody i protestu na istniejąca rzeczywistośćco. Po śmierci ks. Jerzego Popiełuszki także tam odbywały się msze św. za jego duszę, wieczory poezji oraz impresje plastyczne przygotowane przez sopockich twórców, bardzo często przy świecach tworzących nastrój.

Po zniesieniu stanu wojennego Galeria św. Michała nie zakończyła działalności. Bardzo ważnym wydarzeniem było wykonanie III Symfonii Witolda Lutosławskiego 26 VIII 1984 r. w ramach drugoobiegowej imprezy „Gdański Sierpień '84', w obecności kompozytora. Prawykonanie III Symfonii nastapiło w Chicago 29 IX 1983 r. Lutosławskiemu przyznano podziemną Nagrodę Komitetu Kultury Niezależnej „Solidarność” za rok $1983^{51}$.

Należy też wspomnieć o spotkaniach dyskusyjnych pt. „Obecność”, symbolicznie manifestujacych postawę przeciw, w których uczestniczyli m.in.: Szczepański, Jerzy Turowicz czy Krzysztof Zanussisi ${ }^{52}$, ważnej wystawie pt. „Plastycy stoczniowcom”, zorganizowanej w 1985 r., która była spontaniczną reakcją na zabójstwo ks. Popiełuszki ${ }^{53}$; z kolei w rocznicę Sierpnia '80

${ }^{49}$ K. Niedałtowski, Galeria św. Michała $w$ Sopocie. Fragmenty rozmowy z Elżbieta Trybus, Gdańsk, październik 2006, w: Niepokora..., s. 75; Relacja ks. Krzysztofa Niedałtowskiego z września 2014 r., w zbiorach autorki.

${ }_{50}$ Relacja ks. Krzysztofa Niedałtowskiego z września 2014 r., w zbiorach autorki.

${ }^{51}$ Zob. http://ninateka.pl/audio/witold-lutoslawski-iii-symfonia-aksamitna-kurtyna-2-koncert-inauguracyjny (dostęp: 20 III 2017).

${ }^{52}$ Relacja ks. Krzysztofa Niedałtowskiego z września 2014 r., w zbiorach autorki.

${ }^{53}$ Wśród innych wystaw dedykowanych pamięci ks. Popiełuszki można wymienić: „Przeciw złu, przeciw przemocy”, zorganizowaną w Mistrzejowicach w 1985 r., oraz „Czas smutku, 
zaprezentowano cykl rysunków satyrycznych pt. „Czerwone świnie”, po czym o. Słoma w jeszcze większym stopniu znalazł się na cenzurowanym.

Stan wojenny przyczynił się do wypełnienia kościołów ludźmi, w tym nie tylko wierzacymi, co było szczególnie widoczne właśnie u gdańskich dominikanów, gdzie pojawiali się przedstawiciele świata nauki, sztuki, opozycji, młodzieży szkolnej i akademickiej różnych poglądów - wszyscy, którzy odnajdywali się we wspólnocie niezależnej myśli. W Trójmieście wyodrębnił się pewien niewypowiadany podział: kościół św. Brygidy z ks. prałatem Jankowskim przyciagał robotników, stoczniowców, gdańscy pallotyni oraz gdyński kościół Najświętszej Maryi Panny Królowej Polski - inteligencję, a u redemptorystów ze Stella Maris w Gdyni najwięcej było marynarzy i ludzi morza, którymi opiekował się ks. Edward Ryba. Z kolei legendarny proboszcz parafii Najświętszego Serca Pana Jezusa w Gdyni ks. Hilary Jastak w stanie wojennym wspierał uwięzionych i internowanych oraz opozycyjne podziemie Trójmiasta ${ }^{54}$.

Rola Kościoła w stanie wojennym była nie do przecenienia zarówno w sferze duchowej, jak i materialnej. To do kościołów Trójmiasta kierowano pierwsze kroki po informacje oraz z wiadomościa, kto się ukrywa, a kogo zamknęli ${ }^{55}$. 17 XII 1981 r. w reakcji na internowanie działaczy politycznych i ludzi kultury pod patronatem prymasa Józefa Glempa powołano Prymasowski Komitet Pomocy Osobom Pozbawionym Wolności i ich Rodzinom, który udzielał wsparcia internowanym i ich bliskim, zbierał informacje o losie i miejscu pobytu internowanych, dostarczał paczki żywnościowe, lekarstwa i odzież, a dla najbardziej potrzebujących także pieniądze. Skupionych wokół niego było wiele znamienitych osobowości - społeczników i artystów. Każda większa parafia została podzielona na kilka stref, dzięki czemu rozprowadzanie pomocy odbywało się dość sprawnie ${ }^{56}$. W gdańskim kościele św. Brygidy powołana wówczas Komisja Charytatywna zajmowała się wspieraniem rodzin, a nadzorował ją sprawny menadżer ks. Jankowski, który dzięki dobrym kontaktom z Polonią amerykańską uzyskiwał ogromne transporty leków przeznaczane dla pomorskich szpitali. Ponadto wspomagał finansowo wiele osób, podziemie solidarnościowe, któremu przekazywał sprzęt i materiały poligraficzne przemycane w zagranicznych darach, dzieciom organizował kolonie, wspierał

czas nadziei” z 1985 r. i „Pieta Polska” z 1986 r., prezentowane w kościele Matki Boskiej Bolesnej w Poznaniu. Najgłośniejszy oddźwięk miały wystawy problemowe, takie jak „Znak krzyża” z 1983 r., prezentowana w kościele Miłosierdzia Bożego w Warszawie, „Apokalipsa, światło w ciemności” z 1984 r. z kościoła św. Krzyża w Warszawie oraz „W stronę osoby” z klasztoru oo. Dominikanów w Krakowie z 1985 r. (T. Boruta, op. cit., s. 29).

${ }^{54}$ K. Wójcicki, Rozmowy z księdzem Hilarym Jastakiem, Gdynia 2014, s. 220-223.

${ }^{55}$ Archiwum Instytutu Pamięci Narodowej, KM MO Gdańsk-Południe 1, Dobowe meldunki o sytuacji społeczno-politycznej na terenie Gdańska, 16 XII 1981-10 V 1982 r., Meldunki z 21 XII 1981 r., k. 19-21; Relacja Piotra Adamowicza z lutego 2012 r., w zbiorach autorki.

56 S. Bogdanowicz, W ostrzeliwanej Bazylice, w: Świadectwa stanu wojennego, oprac. A. Dudek, K. Madej, Warszawa 2001, s. 27-31. 
chorych i niepełnosprawnych. Był bardzo ofiarny w przekazywaniu pomocy i czerpał autentyczna satysfakcję z jej niesienia ${ }^{57}$.

W parafii NMP KP w Gdyni organizowano pomoc dla rodzin oraz opiekę nad pustymi mieszkaniami, szczególnie tymi, w których zwierzęta zostały same, z kolei redemptorysta ks. Ryba wspierał spotkania grup konspiracyjnych i poszczególnych ukrywających się ludzi, którym dostarczał żywność i bibułę, a wszystko to działo się w kościele naprzeciwko komisariatu Milicji Obywatelskiej. Niezwykle ważna była również pomoc parafii niemieckich, które przekazywały transporty z żywnością i odzieżą; dzięki niej relacje nawiązane $\mathrm{w}$ tamtym okresie przetrwały do dziśs ${ }^{58}$. Sympatia dla Polski ze strony zachodnioniemieckiego społeczeństwa była autentycznym wyrazem solidarności z losem sąsiadów, a przekazywana pomoc humanitarna stanowiła znaczący akt w rozwoju stosunków polsko-zachodnioniemieckich ${ }^{59}$.

Stan wojenny wiele zmienił w środowisku aktorskim - teatralnym, filmowym - przez lata uchodzącym za uprzywilejowanych podopiecznych władzy. Część artystów wyjechała z konieczności za granicę, część zaangażowała się w działania kultury niezależnej. Aktorzy, będący dotąd narzędziem propagandy, w stanie wojennym stali się świadomi swej roli i potrafili zdecydowanie się przeciwstawić, choćby przez uczestnictwo w bojkocie, o którym pisałam wcześniej. Niezależny ruch artystów skupionych wokół Kościoła przybrał charakter niemal masowy i był zjawiskiem bezprecedensowym w polskiej kulturze lat osiemdziesiątych. Twórcy, którzy odrzucali cała politykę kulturalną władz komunistycznych, a chcieli być w ,jakimś” kontakcie ze społeczeństwem, nie pozostali również obojętni na religię, której symboli używali w proteście przeciw stanowi wojennemu. Kościół katolicki w tym czasie odniósł wyraźne zwycięstwo, gdyż bardzo zyskał tym, że nie wykorzystywał swojej pozycji, przeciwnie - pomagał i dzięki szczerości był pozytywnie odbierany. Hierarchowie, tak jak zresztą wielu Polaków, czerpali inspirację z nauczania papieża Jana Pawła II, m.in. dlatego, że przekaz Ojca Świętego był czymś zupełnie innym od tego, co zazwyczaj ludzie słyszeli ${ }^{60}$.

Oprócz niepokornych aktorów niezgodę na poczynania władz wyrażali w zdecydowany sposób także pisarze. Stan wojenny negatywnie wpłyną na funkcjonowanie związków twórczych, a ich sytuacja finansowa stała się katastrofalna. Zawieszenie działalności Związku Literatów Polskich (ZLP) sparaliżowało ich działalność, a szczególnie dużym zaskoczeniem dla całego środowiska było internowanie ludzi pióra ${ }^{61}$. Tuż przed świętami Bożego

57 Relacja Jerzego Kiszkisa z grudnia 2016 r., w zbiorach autorki.

58 Relacja Krzysztofa Niedałtowskiego z września 2014 r., w zbiorach autorki.

${ }_{59}$ D. Pick, Ponad żelaznq kurtyna. Kontakty społeczne między PRL i RFN w okresie détente $i$ stanu wojennego, Warszawa 2016, s. 325.

${ }^{60}$ Relacja Leszka Biernackiego z lutego 2017 r., w zbiorach autorki.

${ }^{61}$ S. Ligarski, Polityka władz komunistycznych wobec twórców kultury w latach 1945-1989, w: Pokolenie '80..., s. 63. 
Narodzenia dekretem o stanie wojennym i zarządzeniem Ministerstwa Kultury i Sztuki z 21 XII 1981 r. rozwiązano kwartalnik literacki „Punkt. Almanach gdańskich środowisk twórczych”, wydawany przez Wydawnictwo Morskie. Ukazywał się on w latach 1978-1981 w nakładzie 800 egzemplarzy. Łącznie powstało 14 numerów. Czasopismo utworzono z inicjatywy Gdańskiego Towarzystwa Przyjaciół Sztuki i publikowano w nim prozę, poezję, publicystykę, przekłady, recenzje oraz noty dotyczące wydarzeń artystycznych na Wybrzeżu. Ostatecznie na skutek rozłamu w zespole redakcji i nacisków części środowiska literackiego, skupionego w gdańskim oddziale nowo powstałego Stowarzyszenia Pisarzy Polskich, przestał wychodzić. W październiku 1982 r. ukazał się pierwszy numer publicystyczno-literackiego pisma podziemnego „Skorpion”, w 1983 r. pojawił się „Podpunkt. Gdańskie zeszyty literackie”, wydawany przez oficynę Kształt, a od czwartego numeru przez Niezależna Oficynę Wydawniczą (NOW-a). W skład redakcji weszli: Andrzej Dorniak, Dariusz Filar, Aleksander Jurewicz, Kazimierz Nowosielski, Stanisław Rosiek, Tadeusz Skutnik, a ich łącznikiem był Marian Terlecki. Na łamach pisma ukazywały się teksty filozoficzne poświęcone zjawiskom literatury i sztuki, a także sprawom społecznym. Publikowali w nim, niekiedy pod pseudonimem, przedstawiciele środowisk literackich, dziennikarskich oraz naukowych Wybrzeża, w tym Lech Bądkowski i Stanisław Dąbrowski, autor poematu pt. Męczeństwo księdza Jerzego Popiełuszki. Drukowano również teksty zagranicznych filozofów i pisarzy, takich jak Alain Besançon, Horst Bienek, Umberto Eco, William Golding, Günter Grass, Aleksandr Zinowjew. Całkiem liczne było również Koło Młodych zawieszonego ZLP, które w Sierpniu ’80 poparło 21 postulatów. Wielu młodych wywodziło się z Uniwersytetu Gdańskiego. Jeden z członków redakcji, Jurewicz, poza prasa podziemną i katolicka, publikował także w miesięczniku Zrzeszenia Kaszubsko-Pomorskiego „Pomerania”, które udostępniło swe łamy licznym autorom opozycyjnym. Część aktywów pisma „Punkt” przejał w późniejszym czasie dwumiesięcznik „Autograf. Literatura, sztuka, krytyka”, wydawany przez Gdańskie Towarzystwo Przyjaciół Sztuki, pod redakcją Andrzeja Krzysztofa Waśkiewicza. Periodyk ten ukazywał się w latach 1988-1990, a o publikowanie w nim zabiegało środowisko literackie Trójmiasta. Oprócz prozy i poezji ważne miejsce zajmowały w piśmie teksty eseistyczne oraz recenzje literackie, teatralne, plastyczne i muzyczne ${ }^{62}$.

W nie mniej trudnej sytuacji byli również plastycy. Związek Polskich Artystów Plastyków (ZPAP) Oddział Gdański, którego historia sięgała 1929 r., gdy w Gdyni powstał Związek Plastyków Pomorskich, został zawieszony. Po odwieszeniu ZPAP działał oficjalnie, ale niedługo, gdyż 20 VI 1983 r. został rozwiązany i władze powołały jego likwidatora. Odtąd wszelkie przejawy aktywności związku w całym kraju miały charakter nielegalny. Do 1982 r.

${ }^{62}$ S. Rosiek, Rewolucja $w$ przestrzeni mowy. Fragment rozmowy z Piotrem Millatim, październik 2006, w: Niepokora..., s. 102-104. 
nie podejmowano w dziedzinie twórczej żadnych inicjatyw, mimo że Oddział Gdański ZPAP zrzeszał tysiąc twórców ${ }^{63}$. Biuro Wystaw Artystycznych w Sopocie długo nie otwierało swoich podwojów, choć realizowało program artystyczny dla zorganizowanych grup szkolnych, jednak plastyka była najsłabiej rozwiniętą dziedzina ${ }^{64} .10 \mathrm{~V} 1983 \mathrm{r}$. zainaugurowano wystawę pt. „Plakat polityczny '82”, na której zaprezentowano retrospektywny przegląd wydawnictw plakatowych wydanych po 13 XII 1981 r., ukazujących „walkę propagandowa z kontrrewolucja oraz działania na rzecz normalizacji życia w Polsce w okresie stanu wojennego"65. Romuald Bukowski, malarz i rysownik plakacista zasłużony dla sopockiego wystawiennictwa, nie pełnił już wówczas funkcji dyrektora BWA. Ten były poseł, który w styczniu 1982 r. jako jedyny głosował przeciwko ustawie zatwierdzającej dekret o stanie wojennym, organizował pomoc dla pozbawionych pracy twórców i internowanych członków NSZZ „Solidarność”, gdyż ich sytuacja egzystencjalna należała do szczególnie trudnych. Ze względu na brak materiałów do pracy nie mogli tworzyć, a wykonywana przez nich sztuka nie przynosiła żadnych dochodów ${ }^{66}$. Już po zniesieniu stanu wojennego, w 1985 r., zorganizowano ważną wystawę pt. „Artyści Gdańska w Paryżu”. 13 X 1989 r., kiedy związek reaktywowano, jego prezesem został Bukowski. Związek nie odzyskał majątku utraconego po delegalizacji, m.in. siedziby w Sieni Gdańskiej, oficyny przy ul. Piwnej i Domu Pracy Twórczej w Strzelnie ${ }^{67}$.

Bardziej ożywiony ruch twórczy rozpoczął się dopiero w drugiej połowie lat osiemdziesiątych za sprawą aktywności Witosława Czerwonki, późniejszego prorektora Akademii Sztuk Pięknych w Gdańsku. W latach 1980-1982 współtworzył z Romanem Usajewiczem nowatorski program Pracowni Podstaw Projektowania, który rozwijał i prowadził z Wojciechem Zamiarą aż do 1993 r.; na bazie tych doświadczeń powstała Pracownia Intermedialna „PI”. Z kolei wraz z Adamem Harasem i Jerzym Ostrogórskim organizował galerię sztuki konceptualnej AUT w Gdańsku, a także Galerię OUT przy BWA w Sopocie. Bardzo ważne, szczególnie dla młodzieży, okazały się wykłady z historii sztuki prowadzone przez Ryszarda Ziarkiewicza oraz wystawa z 1986 r.,

${ }^{63}$ AP Gdańsk, KW PZPR, sygn. 882, Protokoły posiedzeń Sekretariatu KW PZPR, wrzesień-październik 1982 r., Ocena sytuacji politycznej w środowisku kultury województwa gdańskiego, wrzesień 1982 r., k. 105-127.

${ }^{64}$ Ibidem, sygn. 1975, Wydział pracy Ideowo-Wychowawczej. Dokumenty Komisji Kultury KW PZPR, k. 1-10, Główne zadania w zakresie upowszechniania kultury dla dzieci i młodzieży, 1983.

${ }^{65}$ Ibidem, sygn. 937, XVI Zwyczajna Sesja WRN 1983. Sejmowa Komisja Kultury 1983-1989. Uchwały WRN 1982, Związek Polskich Artystów Plastyków - informacja, 26 X 1982 r., k. 63-64.

${ }^{66}$ Ibidem.

${ }^{67}$ Zob. http://www.gedanopedia.pl/?title=ZWI\%C4\%84ZEK_POLSKICH_ARTYST\%C3\%93W_ PLASTYK\%C3\%93W._OKR\%C4\%98G_GDA\%C5\%83SKI (dostęp: 10 VII 2014). 
na której pokazywano prace młodych twórców. W drugiej połowie dekady wielu artystów Akademii Sztuki Pięknych w Gdańsku uczestniczyło w ruchu młodej sztuki, tzw. ekspresji lat osiemdziesiątych. Byli to m.in.: Janusz Akermann, Grzegorz Klaman, Marek Model i Sławomir Witkowski. Na Wyspie Spichrzów, wokół plenerowej pracowni rzeźby PWSSP, a następnie w Galerii Wyspa działała jedna z alternatywnych grup twórczych, z których wyłoniła się tzw. nowa szkoła gdańska, z Klamanem i Kazimierzem Kowalczykiem na czele. Latem 1986 r. w sopockim BWA zorganizowano wystawę pt. „Ekspresja lat osiemdziesiątych", podsumowująca podejmowane w pierwszej połowie dekady działania artystów reprezentujących ten nurt. Wyprzedzała ona o rok podobne wydarzenia w głównych ośrodkach kulturalnych kraju, aczkolwiek trzeba przyznać, że ze względu na półoficjalny charakter ekspozycji i ustronne położenie Sopotu nie spotkała się z większym odzewem.

Podobnie dla fotografii stan wojenny stał się wyraźną cezura, która zapoczątkowała zupełnie innego rodzaju twórczość, niejako wymuszona wydarzeniami politycznymi. Fotograficy odcinający się od oficjalnego życia artystycznego i również jak reszta twórców bojkotujący państwowe galerie, przestali działać. Zamknięto gdańskie placówki, w tym Galerię GN kierowana przez Leszka Brogowskiego, późniejszego wykładowcę paryskiej Sorbony ${ }^{68}$. Zarówno w sztuce, jak i fotografii zaczęły dominować treści egzystencjalne, społeczne i patriotyczno-religijne, tym razem wyrażane za pomocą innych niż dotychczas form artystycznych ${ }^{69}$.

Sierpień '80 oraz stan wojenny zaowocowały rozkwitem sztuki fotoreportażu. Ponura rzeczywistość stanu wojennego, strajki i manifestacje, a także ważne symboliczne wydarzenia, jak śmierć Grzegorza Przemyka czy ks. Popiełuszki oraz wizyty Jana Pawła II, były przedmiotem zainteresowania gdańskich fotoreporterów Janusza Bałandy Rydzewskiego, Leszka Biernackiego, Stefana Figlarowicza, Zbigniewa Kosycarza, Bogusława Nieznalskiego, Stanisława Składanowskiego i Leonarda Szmaglika. Wszyscy oni pracowali w bardzo trudnych warunkach. Kosycarzowi udało się wykonać zdjęcia z pierwszych dni stanu wojennego. Uwiecznił na nich pojazdy opancerzone, zamieszki, życie codzienne, a później demonstracje majowe z $1982 \mathrm{r}$. Artysta fotografik, wykładowca akademicki i wieloletni kierownik Gdańskiej Galerii Fotografii ZPAF Figlarowicz w okresie jawnej i legalnej działalności „Solidarności” i w czasie stanu wojennego wykonał wiele fotografii, które należą dziś do najwartościowszych zapisów dokumentalnych tamtego czasu.

${ }^{68}$ K. Jurecki, Fotografia polska lat 80, http://www.kultura-niezalezna.pl/rkn/fotografia/8567,Fotografia-polska-lat-80.html (dostęp: 2009-2010).

69 Ł. Guzek, Galeria jako zagadnienie artystyczne w sztuce konceptualnej, „Sztuka i Dokumentacja” 2012, nr 6, s. 123-130. Fotografka Anna Bohdziewicz w „Fotodzienniku”, tworzonym od 1982 r., prezentowała polską rzeczywistość, w tym paradoksy życia codziennego. Pokazywała kolejki, puste półki sklepowe, strajki, czasem wesołe chwile. 
Nieznalski robił zdjęcia 13 grudnia w Stoczni Gdańskiej. Zarejestrował na nich spontaniczny opór społeczeństwa co do decyzji WRON. W trakcie wywoływania zdjęć filmy zaraz po opracowaniu były przez niego natychmiast ukrywane, gdyż jak sam wspominał, czuł się obserwowany. Wykonał również zdjęcia - pocztówki patriotyczne, z prywatnego spotkania papieża Jana Pawła II z Wałęsa oraz z budowy pomnika Poległych Stoczniowców. 31 VIII 1982 r. w czasie fotografowania dużej manifestacji patriotycznej nieopodal kościoła Mariackiego w Gdańsku został postrzelony przez ZOMO, a 13 III 1983 r. złapano go w pobliżu pomnika i przetrzymywano przez kilkanaście godzin, później był kilkakrotnie wzywany przez SB na przesłuchania ${ }^{70}$. Jego zdjęcie No pasaran, przedstawiające kordon strajkujących robotników ze Stoczni Gdańskiej i blokujących przejście, zdobyło Grand Prix w Poznaniu w 1985 r. i w Andorze dwa lata później. W 1989 r., w rocznicę 150-lecia narodzin fotografii, praca ta została zaliczona do 10 najlepszych $\mathrm{w}$ historii polskiej fotografii. Z kolei najbardziej znane zdjęcie Bałandy Rydzewskiego przedstawia kordon funkcjonariuszy ZOMO stojących pod lufami czołgów w staranowanej w grudniu 1981 r. bramie Stoczni Gdańskiej. Inne ukazuja samą bramę, wyłamaną i pogięta, porzucone stoczniowe kaski w miejscu jej pacyfikacji. Z października 1982 r. pochodzi fotografia pokazująca, jak grupa ludzi ciagnie i popycha śmietnik; byli to uczestnicy manifestacji przeciw delegalizacji NSZZ „Solidarność”, którzy użyli go jako część ulicznej barykady. Prace Bałandy Rydzewskiego wyróżnia ekspresja i poza funkcja dokumentacyjna także walor artystyczny ${ }^{71}$.

Składanowski w pierwszych dniach stanu wojennego robił zdjęcia zomowcom, niestety ostatecznie filmy zostały mu zarekwirowane. W czasie manifestacji majowej udało mu się wykonać zdjęcie pod pomnikiem Trzech Krzyży w Gdańsku, mimo że ZOMO pilnowało, by nikt do niego nie podszedł. Do dziś znane są jego dwie fotografie pokazujące, jak zomowcy ruszali na tłum ${ }^{72}$. Szmaglik, który towarzyszył ze swoim aparatem „Solidarności”, w stanie wojennym nie uczestniczył w manifestacjach, choć w 1984 r. zrobił kilka zdjęć podczas występu aktorów w Kaplicy Królewskiej w Gdańsku, a później w czasie strajku w sierpniu $1988 \mathrm{r}^{73}$ Biernacki w pierwszych dniach stanu wojennego fotografował strajk na Uniwersytecie Gdańskim i w Stoczni Gdańskiej, lecz część materiałów bezpowrotnie przepadła z powodu prześwietlenia filmu $\mathrm{w}$ trakcie jego wywoływania. Jak wspominał, wykonywanie zdjęć w tamtym czasie wiązało się z odwagą i rozwaga, wymagało też wielkiej ostrożności, bo wszędzie na ulicach były ciagłe kontrole i rewizje, a nikt nie chciał ryzykować

\footnotetext{
70 Zob. http://www.wszechnica.solidarnosc.org.pl/?page_id=16282 (dostęp: 7 XII 2010); http:// www.gedanopedia.pl/index.php?title=NIEZNALSKI_BOGUS\%C5\%81AW (dostęp: 4 I 2015).

${ }^{71}$ Zob. http://trojmiasto.wyborcza.pl/trojmiasto/1,35636,15662232,Nie_zyje_fotograf_Solidarnosci_autor_slynnych_zdjec.html (dostęp: 24 III 2014).

72 Zob. http://www.wszechnica.solidarnosc.org.pl/?page_id=13298 (dostęp: 9 XII 2010).

${ }^{73}$ Zob. http://www.wszechnica.solidarnosc.org.pl/?page_id=13485 (dostęp: 1 XII 2010).
} 
utraty sprzętu ani mieć kłopotów z zatrzymaniem. Jego zdjęcia z demonstracji 1- i 3-majowych 1982 r., powrotu Wałęsy z internowania oraz manifestacji 31 VIII 1983 r. są cennym źródłem wiedzy o niecodzienności stanu wojennego ${ }^{74}$.

Stan wojenny wypchnął wielu fotografów i artystów w obszar sztuki kościelnej, a powrót do normalnego życia artystycznego następował ok. 1986 r., choć nie był to w żaden sposób czas swobody twórczej. Związek Artystów Fotografików zrzeszał tylko 30 członków, a w Gdańskim Towarzystwie Fotograficznym działało 120 artystów, którzy podobnie jak plastycy nie mogli pracować, gdyż brak materiałów fotograficznych, czyli klisz, utrwalaczy, filmów, odczynników, doskwierał w Trójmieście znacznie bardziej niż w innych częściach kraju, tak jak brak dostępu do sprzętu czy pomieszczeń umożliwiajaccych wykonywanie zawodu ${ }^{75}$. Można tylko przypuszczać, że wynikało to z celowego działania władz, by akcesoria fotograficzne nie docierały do tak newralgicznego regionu Polski. W'sród gdańskich imprez realizowanych o zasięgu ogólnopolskim znajdowały się: konkurs fotografii „Złocisty Jantar”, „Salony Portretu” oraz Biennale Fotografiki Krajów Nadbałtyckich.

Nad nurtem sztuki oficjalnej czuwały władze, które zabiegały o zachowanie pozorów normalności, organizując imprezy typu „Ja i moje miasto” w Gdańsku czy „Sopot kuźnią młodych talentów” lub te o charakterze ludowym, jak „Pasowanie Kosiarza” i „Skarszewskie Sobótki” oraz wystawy sztuki ludowej, pracy rękodzielniczej i różne imprezy muzyczne. Wspierano zespoły amatorskie, wśród których najważniejszą rolę odgrywały: Teatr OM z Sopotu, Teatr Poezji z Pałacu Młodzieżowego w Gdyni, Cyrk Przemka z Gdańska-Przymorza i Kapela Portowa z Młodzieżowego Domu Kultury w Gdańsku-Nowym Porcie. Popularyzacji amatorskiej twórczości artystycznej miały służyć konkursy recytatorskie, Konfrontacje Teatrów Amatorskich, Przegląd Teatrów Lalkowych, Przegląd Teatrów przy Kawie, Przegląd Amatorskich Zespołów Muzycznych, Konkurs Recytatorski Literatury Kaszubsko-Pomorskiej, Ogólnopolski Konkurs Piosenki Radzieckiej, Turniej Talentów Tanecznych, Wojewódzkie Mistrzostwa Zespołów Tanecznych oraz Festiwal Piosenki Wakacyjnej ${ }^{76}$.

W styczniu 1982 r. zaczęły działać kina: Leningrad i Bajka w Gdańsku, Bałtyk w Sopocie oraz Warszawa w Gdyni. Zezwolono na seanse przedpołudniowe dla dzieci w soboty i niedziele oraz jeden dla dorosłych w godzinach wieczornych. Z założenia uruchomiono tylko jedno kino w mieście i miało

${ }^{74}$ Relacja Leszka Biernackiego z lutego 2017 r., w zbiorach autorki.

75 AP Gdańsk, KW PZPR, sygn. 882, Protokoły posiedzeń Sekretariatu KW PZPR, Ocena sytuacji politycznej w środowisku kultury województwa gdańskiego, wrzesień 1982 r., k. 105-127; ibidem, sygn. 937, XVI Zwyczajna Sesja WRN 1983. Sejmowa Komisja Kultury 1983-1989. Uchwały WRN 1982, Związek Polskich Artystów Fotografików, 19 X 1982 r., k. 67-68; „Dziennik Bałtycki”, 6 X 1982.

${ }^{76}$ AP Gdańsk, KW PZPR, sygn. 937, XVI Zwyczajna Sesja WRN 1983. Sejmowa Komisja Kultury 1983-1989. Uchwały WRN 1982, Tezy do opracowania „Warunki rozwoju kultury w woj. gdańskim, 14 X 1982 r., k. 38-39. 
one prezentować wyłącznie filmy dopuszczone do wyświetlania według tzw. zestawu warszawskiego, który wpłyną z Centralnego Zarządu Rozpowszechniania Filmów, w porozumieniu z Głównym Urzędem Kontroli Publikacji i Widowisk oraz po zaakceptowaniu przez komisarza wojskowego. Wybrany repertuar przedstawiał się następująco: dla kina Leningrad w Gdańsku filmy Czute miejsca, Bestia, Hallo, Szpicbródka, Powrót Mechagodzilli, Superpotwór; dla kina Warszawa w Gdyni: Czułe miejsca, Spirala, Nie zaznasz spokoju, Przygody Calineczki, Colargol na Dzikim Zachodzie, Powrót Mechagodzilli. W sopockim kinie Bałtyk dopuszczono do projekcji takie filmy, jak Wielka majówka, Zmory, Superpotwór, Dzieci wśród piratów, Wielka podróż Bolka $i$ Lolka. W kinie Bajka dla dzieci wyświetlano następujace filmy: Colargol zdobywca kosmosu, Proszę stonia, Dzieci wśród piratów, Przygody Calineczki, a dorośli mogli tam obejrzeć Wielki podryw, Zdjęcia próbne, Ćmę oraz Wielka majówkę $e^{77}$. Do kas kinowych ustawiały się długie kolejki oczekujących. Należało przeznaczyć kilka godzin, by zdobyć bilet, ale zawsze można go było nabyć bezpośrednio u „konika”, czyli osoby oferującej jego zakup bez tracenia czasu, choć za odpowiednio wyższą cenę. Od 1 VI 1982 r. weszły w życie nowe ceny biletów do kin i w zależności od miejsca trzeba było zapłacić od 30 do $60 \mathrm{zł}$, niemal tyle co za obiad w barze mlecznym. Bilety na seanse trwające ponad trzy godziny kosztowały podwójnie, a dla dzieci 10 lub 15 zł za film pełnometrażowy. Dla porównania cena gazety codziennej wzrosła do $5 \mathrm{zł}^{78}$. W kinach dla najmłodszych prowadzono akcje pt. „Z filmem na ty” lub „Pożegnanie z filmem”, ale takie imprezy występowały w znikomej liczbie. Nieco później, w 1983 r., na ekranach kin pojawiły się hity - polska komedia kryminalna Vabank oraz produkcja amerykańska Wejście smoka z Bruce'em Lee w roli głównej ${ }^{79}$.

W Telewizji Polskiej, gdzie od 13 XII 1981 r. dostępny był tylko jeden program telewizyjny (od 15 II 1982 r. powrócono do nadawania TVP 2, mającego charakter kulturalno-rozrywkowy), dominowały liczne powtórki teatralne oraz prezentacje filmów ze Związku Radzieckiego i Czechosłowacji, a absolutnym przebojem okazał się czechosłowacki serial Szpital na peryferiach ${ }^{80}$. Podobnie jak w telewizji ogólnopolskiej, również w ośrodku gdańskim w programie informacyjno-publicystycznym „Panorama”, nadawanym w godz. 19-19.30, prezenterzy występowali $\mathrm{w}$ mundurach ${ }^{81}$. Tak jak wszyscy dziennikarze

77 Ibidem, sygn. 1983, Wydział Pracy Ideowo-Wychowawczej. Protokoły Wojewódzkiego Sztabu Informacji i Propagandy 1981-1983, Ustalenia WSZIiP, 5 I 1982 r., k. 31.

78 „Głos Wybrzeża”, 31 V 1982.

79 D. Skotarczak, Obraz społeczeństwa PRL w komedii filmowej, Poznań 2004, s. 246.

${ }^{80}$ A. Kozieł, Za chwile dalszy ciag programu... Telewizja Polska czterech dekad 1952-1989, Warszawa 2003, s. 251.

81 „Panorama” była nadawana od poniedziałku do piątku, w sobotę emitowano w tym czasie magazyn kulturalny. AP Gdańsk, KW PZPR, sygn. 1983, Wydział Pracy Ideowo-Wychowawczej. Protokoły Wojewódzkiego Sztabu Informacji i Propagandy, Notatka z posiedzenia Wojewódzkiego Sztabu Informacji i Propagandy 21 I 1982 r., godz. 10.00, 1981-1983, k. 67. 
redakcja gdańskiego ośrodka TVP przeszła wnikliwą weryfikację. Odwołano Jerzego Afanasjewa, głównego reżysera gdańskiego ośrodka, za manifestowanie negatywnego stosunku do stanu wojennego i złożenie legitymacji partyjnej 16 grudnia, ponadto Piotra Szalkego - kierownika redakcji muzycznej, Wiktora Niemirę, operatora dźwięku, za głoszenie wrogich poglądów politycznych, Alicję Hołdun, działaczkę „Solidarności”, wysłano na rentę, a Hannę Kordalska odwołano za kolportowanie ulotek oraz publiczne demonstrowanie wrogości do stanu wojennego. Janusza Trusa zwolniono za realizację błędnych materiałów publicystycznych, okazywanie krytycznego stosunku do gazety wydawanej w czasie strajku prasowego oraz podważanie zasadności wprowadzenia stanu wojennego ${ }^{82}$, toteż do 1983 r. pozostawał bezrobotny. Czesść dziennikarzy lokalnych rozgłośni radia i telewizji, podobnie jak aktorów, również uczestniczyła $\mathrm{w}$ przygotowaniu audycji propagandowych w zakładach pracy, emitowanych przez radiowęzły. Miały to być teksty „rozszerzające świadomość”, czym jest stan wojenny, jak likwidować podziały wśród ludzi oraz tworzyć atmosfere integracji ${ }^{83}$. Wytypowani dziennikarze gdańskiego ośrodka telewizji i radia mieli przekazywać do telewizji warszawskiej „rzetelne opinie” o regionie gdańskim, ustalone wcześniej przez Wojewódzki Sztab Informacji i Propagandy ${ }^{84}$.

Natomiast w TVP Gdańsk w soboty o godz. 19.00 emitowano Errate tygodnik kulturalny, od czerwca $1982 \mathrm{r}$. w trzecią niedzielę miesiąca o godz. 13.30 30-minutowy odcinek z cyklu „Kultura wsi i małych miasteczek”, a od września cykl „Gdańsk, jego historia i teraźniejszość”" ${ }^{85}$. W stanie wojennym bardzo zyskały wszelkie programy rolnicze oraz publicystyka wojskowa, a przykładem były prezentowane w gdańskiej rozgłośni radiowej materiały o tematyce młodzieżowej, w tym audycje ze wsi, takie jak reportaż dźwiękowy o drugim pokoleniu w Spółdzielni Produkcyjnej Kulice, dwa felietony dnia na tematy młodzieżowe przed Plenum KW, rozmowy ze stoczniowcami i portowcami pt. „Jak widzę swoją pracę lub mój udział w pracy organizacji młodzieżowych", magazyny artystyczne o młodych twórcach ludowych czy audycje poświęcone samookaleczeniu się młodych narkomanów ${ }^{86}$.

Mieszkańcy Trójmiasta dość dotkliwie odczuwali brak dostępu do placówek kultury. Dotyczyło to przede wszystkim nowych, dużych osiedli, przez co

82 Ibidem, sygn. 2257, Oceny pracy dziennikarzy przez zespół weryfikacyjny, Protokół posiedzenia zespołu weryfikacyjnego 9 I 1982 r., 23 I 1982 r., k. 16.

${ }^{83}$ Ibidem, sygn. 1983, Wydział Pracy Ideowo-Wychowawczej. Protokoły Wojewódzkiego Sztabu Informacji i Propagandy, Notatka z posiedzenia Wojewódzkiego Sztabu Informacji i Propagandy 20 XII 1981 r., godz. 12.00, 1981-1983, k. 21.

${ }^{84}$ Ibidem, Notatka z posiedzenia Wojewódzkiego Sztabu Informacji i Propagandy 21 XII 1981 r., godz. 15.00, 1981-1983, k. 24.

${ }^{85}$ Ibidem, sygn. 937, XVI Zwyczajna Sesja WRN 1983. Sejmowa Komisja Kultury 1983-1989, Uchwały WRN 1982, Działalność programowa OTV Gdańsk w dziedzinie kultury, 1982 r., k. 112-113.

${ }^{86}$ Ibidem, sygn. 1982, Wydział Pracy Ideowo-Wychowawczej. Dokumenty Rady Redakcyjnej prasy gdańskiej, Komitet ds. radia i telewizji, 1978-1982, k. 159. 
liczba ludności przypadającej na jedną placówkę kulturalną w województwie gdańskim plasowała je na 46 miejscu, ze wskaźnikiem niższym niż średnia krajowa ${ }^{87}$. Fatalna sytuacja finansowa społeczeństwa powodowała odstępowanie od kupowania książek. Zdecydowany problem stanowiły książki dla dzieci, także w zakresie możliwości ich wypożyczenia, gdyż oferta literatury pięknej dla najmłodszych nie przewyższała $15 \%$ zasobu bibliotek ${ }^{88}$. Na wielu osiedlach nie było żadnych punktów i filii bibliotecznych, nastapił więc znaczny spadek działalności kolporterskiej i kiermaszowej, spadała podaż produkcji wydawniczej, tym samym zatracono sens upowszechniania książek, a one same zostały zdegradowane do roli zwykłego towaru. Do pewnych tradycji księgarskich należało odkładanie poszukiwanych egzemplarzy książek dla klientów indywidualnych, dla których książka stanowiła warsztat pracy, czyli dla naukowców, twórców, lekarzy, co jednak podlegało kontroli i traktowano jako praktyki spekulacyjne, toteż dochodziło na tym tle do nieporozumień. W okresie jesienno-zimowym ruch klientów indywidualnych w księgarniach zamierał, a ostatnia godzina handlu była ewidentna strata ${ }^{89}$.

Podobnie martwe pozostawały muzea, ze względu na brak kadry fachowców, działów oświatowych, a także skromne zaplecze techniczne oraz zbyt małe powierzchnie magazynowe ${ }^{90}$. Wśród oferty muzealnej najciekawsze wydawały się zbiory w Muzeum Archeologicznym w Gdańsku oraz organizowane w Muzeum Narodowym „Niedzielne spotkania ze sztuka”. Muzea brały udział w tworzeniu szkolnych izb pamięci i tradycji, a wspólnie z Towarzystwem Przyjaciół Gdańska organizowały konkursy historyczne pt. „Ja i moje miasto”. Z Towarzystwem Miłośników Gdyni wdrażały inicjatywy popularyzujące historię tego miasta i wychowania morskiego, ale zarówno zaplecze kadrowe, jak i instytucjonalne było na bardzo niskim poziomie ${ }^{91}$.

W popularnym we wcześniejszych latach jednym z najstarszych ośrodków kultury studenckiej w Polsce, Klubie Studentów Wybrzeża Żak, w związku z wprowadzeniem stanu wojennego zawieszono działalność i zwolniono wszystkich pracowników. Po ponownym uruchomieniu w $1983 \mathrm{r}$. zainicjowano „Żakowską klinikę jazzu”, promujaccą młodych muzyków, a w 1984 r. Klub Bluesowy im. Alexisa Kornera. Jazz Jantar (1981) wrócił do Żaka i został zorganizowany w kilku miejscach. Na statku (rejs z Sopotu do Gdańska)

${ }^{87}$ Ibidem, sygn. 882, Protokoły posiedzeń Sekretariatu KW PZPR, Ocena sytuacji politycznej w środowisku kultury województwa gdańskiego, wrzesień 1982 r., k. 105-127.

${ }^{88}$ Ibidem, Upowszechnianie czytelnictwa prasy i książki, k. 58-61; ibidem, Sprawozdanie z działalności Stowarzyszeń Księgarzy Polskich w Gdańsku w okresie 1975-1982, [b.d.], k. $40-45$.

${ }^{89}$ Ibidem, Informacja na temat działalności PP „Dom Książki” w Gdańsku, 1983 r., k. 26-31.

${ }_{90}$ Ibidem, Problemy rozwoju kultury województwa gdańskiego, marzec 1983 r., k. 125-169.

${ }^{91}$ Ibidem, sygn. 1975, Wydział Pracy Ideowo-Wychowawczej. Dokumenty Komisji Kultury KW PZPR 1983-1985, Główne zadania w zakresie upowszechniania kultury dla dzieci i młodzieży, 1983 r., k. 1-10. 
koncertowały trójmiejskie zespoły, w Wielkim Młynie m.in. Tomasz Stańko, Trio Jana Ptaszyna Wróblewskiego, Helmut Nadolski z Supergrupa Bez Fałszywej Skromności; w hali Stoczni: Ewa Bem, Stanisław Sojka, Trio Wojciecha Karolaka, Novi Singers, Tomasz Szukalski, Józef Skrzek. Od 1984 r. działalność rozpoczął Dyskusyjny Klub Filmowy (DKF); wraz z Kołem Młodych Polskiego Stowarzyszenia Filmowców organizował festiwal Młode Kino Polskie ${ }^{92}$. Dla wielu młodych ludzi, nie tylko studentów, pojawienie się w Żaku, miejscu narodzin polskiego rock'n'rolla, stanowiło punkt obowiązkowy, a uczestnictwo w projekcjach DKF należało do dobrego tonu, było zaszczytem, nawet marzeniem, oglądało się tam bowiem filmy niedostępne w zwykłych kinach. Podobne emocje wzbudzały sopockie kluby Rancho i Łajba, wyróżniające się przez otwartość na niezależną kulturę i sztukę. Pamiętne były także późniejsze relacje z imprez organizowanych w Łajbie, transmitowanych w radiowej Trójce audycji pt. Noc włóczęgów i poetów, Trzy dni trójki w Eajbie, Sztormy poetyckie, Jarmarki piosenki, Turnieje o koło ratunkowe Łajby oraz dwie edycje Studenckich Ogólnopolskich Prezentacji Otwartych Teatrów SOPOT '84 i '85, które przyciagały liczna publiczność. Łajba firmowała też plakaty poetyckie, tzw. listy gończe, takich poetów, jak Tomasz Jastrun, Antoni Pawlak czy Piotr Bratkowski ${ }^{93}$.

W drugiej połowie lat osiemdziesiątych na Wybrzeżu uwidoczniła się formacja artystyczna Totart, założona w 1986 r. przez performerów, plastyków, poetów i muzyków. Prowadzili swoje akcje, w tym wieczory poetyckie, kabarety, pokazy filmowe i koncerty, m.in. w klubie muzyczno-rozrywkowym Rudy Kot w Gdańsku. Miał on już swoją historię, ugruntowana w latach pięćdziesiątych, gdy odbywały się dyskusje literackie i artystyczne. Działał tam Franciszek Walicki - „ojciec polskiego bigbitu i rocka”, występowały najważniejsze wówczas zespoły muzyczne, pod koniec lat siedemdziesiątych debiutowała Izabela Trojanowska. Współcześnie w miejscu tym zainicjowano powołanie Muzeum Polskiego Rocka ${ }^{94}$. Sytuacja polityczna i jej skutki doprowadziły do załamania całego układu sztuki awangardowej, gdyż najważniejsze grupy zostały rozwiązane, a część artystów i animatorów życia kulturalnego wyjechała za granicę, inni przestali tworzyć lub przeszli do działań prywatnych, poza mecenatem państwowym.

${ }^{92}$ Klub Studentów Wybrzeża Żak przez lata zrealizował wiele przedsięwzięć teatralno-kabaretowych, m.in. Bim-Bom, Teatrzyk Rąk Co To, To-Tu, Cyrk Rodziny Afanasjeff Tralabomba oraz Dyskusyjny Klub Filmowy Studentów i Młodej Inteligencji powołany w 1955 r. Żak miał za sobą okres świetności muzyki jazzowej, co objawiło się na I Ogólnopolskim Festiwalu Muzyki Jazzowej w Sopocie (w 1956 r.), gdzie debiutował Krzysztof Komeda, oraz teatru Bim-Bom, w którym działali m.in. Zbigniew Cybulski, Jacek Fedorowicz i Bogumił Kobiela.

${ }_{93}$ W. Fułek, R. Stinzing-Wojnarowski, Kurort w cieniu PRL-u. Sopot 1945-1989, Gdańsk 2007 , s. 250 .

${ }^{94}$ K. Skiba, J. Janiszewski, P. Konnak, Artyści, wariaci, anarchiści. Opowieść o gdańskiej alternatywie lat 80-tych, Warszawa 2011, s. 19-63. 
Również w latach osiemdziesiątych główną instytucją organizującą imprezy muzyczne i inne kulturalne w Trójmieście była Bałtycka Agencja Artystyczna BART. Pod jej opieką znajdowały się trzy zespoły młodzieżowe: Babsztyl, Camerata i Baltic Jazz Band. Koncerty BART, Teatru Muzycznego, Państwowej Opery i Filharmonii Bałtyckiej, przygotowywane dla żołnierzy Ludowego Wojska Polskiego i funkcjonariuszy MO wiosna 1982 r., z udziałem najlepszych zespołów i solistów Wybrzeża, byłym pewnym miernikiem stanowiska artystów wobec stanu wojennego, gdyż część odmówiła brania udziału w takim przedsięwzięciu, jakkolwiek oficjalny sezon kulturalny Trójmiasta miały otwierać majowe Dni Kultury, Oświaty, Książki i Prasy, wokół których organizowano: 100-lecie polskiego ruchu robotniczego, Dni Zwycięstwa, 35-lecie RSW Prasa-Książka-Ruch, 100-lecie urodzin Karola Szymanowskiego oraz 140. rocznicę urodzin Marii Konopnickiej ${ }^{95}$.

Ze względu na stan wojenny nie odbył się IX Festiwal Polskich Filmów Fabularnych, odwołano także organizowany od 1961 r. Międzynarodowy Festiwal Piosenki w Sopocie, transmitowany przez TVP i prezentujący światowe hity muzyki oraz kolorowa zachodnia modę, gdyż Sopot Festiwal był marka sama w sobie ${ }^{96}$. Przez lata stanowił najważniejsze wydarzenie muzyczne w PRL, okno na świat i - zwłaszcza od drugiej połowy lat siedemdziesiątych, gdy przekształcono go w Festiwal Interwizji - konkurował z Festiwalem Eurowizji. Opera Leśna za sprawą festiwalu szybko stała się atrakcją sopockiego lata i dzięki telewizyjnemu przekazowi obiektem zainteresowania w całym kraju. Początkowo festiwal odbywał się w formule konkursowej, a organizatorem było Ministerstwo Kultury i Sztuki przy współpracy z Polską Agencja Artystyczną Pagart ${ }^{97}$, przy czym bez zgody tej agencji żaden artysta nie mógł wyjechać za granicę. Sopocki Festiwal Interwizji stanowił wydarzenie prestiżowe w całej Europie Wschodniej. Tam rodziły się gwiazdy, rozpoczynały spektakularne kariery, premiery miały przyszłe przeboje, a Sopot stał się miejscem wielkiego sukcesu gwiazd, takich jak Helena Vondráčková, Jiří Korn, Frank Schöbel, Ałła Pugaczowa, Hana Zagorová, Maryla Rodowicz. Oprócz artystów występujących na scenie statusem gwiazd cieszyli się także ulubieni prezenterzy, w tym Krystyna Loska, Lucjan Kydryński, a później

${ }^{95}$ AP Gdańsk, KW PZPR, sygn. 879, Protokoły posiedzeń Sekretariatu KW PZPR, Informacja o programie kulturalnym Wybrzeża w sezonie letnim 1982, 4 VI 1982 r., k. 154-160.

${ }^{96}$ Pierwsza tego typu impreza odbyła się w 1961 r. na terenie Stoczni Gdańskiej i trwała aż sześć dni. Od 1964 r. Sopot Festiwal gościł na deskach Opery Leśnej. Pomysłodawcą Międzynarodowego Festiwalu Piosenki był polski pianista i kompozytor Władysław Szpilman.

${ }_{97}$ Powołany w 1957 r. Pagart miał dbać o promocję polskich artystów za granica oraz sprowadzać do Polski wykonawców z innych krajów. W rzeczywistości był monopolista, gdyż bez jego zgody nikt nie mógł wyjechać na zagraniczny kontrakt lub odwrotnie, wystapić w Polsce. Pełnił jednocześnie funkcję agencji impresaryjnej oraz urzędu paszportowego, któremu zdawało się paszport. Artyści występujący poza Polską płacili Pagartowi prowizję w wysokości $10 \%$ zarobków za występy w krajach socjalistycznych oraz $20 \%$ za koncerty w państwach kapitalistycznych. 
córka Loski Grażyna Torbicka i syn Lucjana (oraz Haliny Kunickiej) Marcin Kydryński. Wprowadzenie stanu wojennego spowodowało zawieszenie festiwalu na cztery lata. Podobnie V Konkurs Tańca Scenicznego i Choreografii przesunięto na 1984 r., a Festiwal Zespołów Folklorystycznych Polski Północnej całkowicie odwołano.

Stan wojenny pozbawił wielu twórców przestrzeni do wykonywania pracy i zarobkowania, a część w zdecydowany sposób nie zgadzała się z narzuconym przez władze profilem działalności. Niszę po zamkniętych instytucjach kultury oraz potencjał ludzi starał się zagospodarowywać Kościół, dzięki któremu rozwijała się sztuka i kultura niezależna. Bez azylu Kościoła nie byłby możliwy rozkwit niezależnych wydawnictw, wolnej prasy, teatru domowego, spotkań i prelekcji. Kościół zdecydowanie wzmocnił swoją pozycję przez nowy wymiar aktywności i rolę, jaką odegrał w działaniach niepodległościowych, ale ludzie kultury w zderzeniu się z reżimem stanu wojennego i zapaścia instytucji zdecydowanie stracili najbardziej.

\section{Streszczenie}

Wprowadzenie stanu wojennego nie pozostało bez wpływu na ludzi kultury, wielu z nich nie mogło wykonywać zawodu z powodu zawieszonej pracy instytucji. Od 13 XII 1981 r. dostęp do oferty kulturalnej został całkowicie ograniczony, dla twórców zamknęła się droga do zarobkowania. W całym kraju środowisko aktorów ogłosiło bojkot mediów, co przerodziło się w najdłuższy strajk stanu wojennego, poparty również przez artystów z Trójmiasta. Wobec blokady twórczej część ludzi kultury udała się na emigrację, część zaangażowała się w podziemne działania kultury niezależnej. Aktorzy odrzucili dotychczasową rolę bycia narzędziem propagandy, dlatego w stanie wojennym stali się świadomymi komentatorami rzeczywistości. W styczniu 1982 r. w Warszawie powstał Komitet Kultury Niezależnej, który wspierał rozmaite wystawy plastyczne, prezentacje teatralne, inicjatywy artystów mające na celu swobodny obieg sztuki, w tym niezależne konkursy, spotkania twórców, działalność wydawniczą i naukową. Komitet wydawał również miesięcznik „Przedświt”, rekomendujący różne wydarzenia kulturalne i inne akcje organizowane wspólnie z Kościołem katolickim. Dzięki powstaniu KKN mogła rozwijać się podziemna, niezależna od władz państwowych kultura i sztuka, a twórcy działający przy dziesiątkach duszpasterstw akademickich, funkcjonujących w okresie legalnej „Solidarności”, które nie zostały rozwiązane, zdobywali uznanie i nagrody oraz wzmacniali podziemne struktury, nadając im jednocześnie nowy wymiar aktywności. Ludzie kultury równie mocno angażowali się w pomoc internowanym i ich rodzinom, wspierali na duchu przestraszonych ludzi.

Na wzór działań okupacyjnych w kraju został uruchomiony teatr domowy, jednak przeznaczony tylko dla zamkniętego grona zaufanych odbiorców, dlatego najbardziej spektakularnie powstałą niszę zagospodarował Kościół katolicki. Stał się on fundamentem działania i dawał schronienie, a także przestrzeń dla twórczości artystycznej. Stan wojenny przyczynił się do wypełnienia kościołów ludźmi, w tym nie tylko wierzącymi, ale wszystkimi, którzy odnajdywali się we wspólnocie niezależnej myśli. Rola Kościoła w stanie wojennym była nie do przecenienia zarówno w sferze duchowej, jak i materialnej, bo właśnie tam kierowano zazwyczaj pierwsze kroki po informacje oraz z wiadomościa, kto się ukrywa, a kogo zamknęli.

Rozkwit kultury niezależnej w Kościele nie byłby możliwy bez wyjątkowych i odważnych ludzi, jak dominikanin o. Sławomir Słoma, przychylny opozycji i do dziś wspominany w Gdańsku 
z wdzięcznościa, przede wszystkim dlatego że przygarniał każdego, kto szukał pomocy. Niezależny ruch artystów skupionych wokół Kościoła przybrał z czasem charakter masowy i był zjawiskiem bezprecedensowym w polskiej kulturze lat osiemdziesiatych. Otwarci hierarchowie, tak jak wielu Polaków, czerpali przykład z papieża Jana Pawła II oraz papieskich pielgrzymek do Polski, bo przekaz Ojca Świętego był inny niż sztuczny język PRL-owskiej nowomowy, kontrastujący z niezwykłym autorytetem i osobowością papieża.

Dla wielu artystycznych dziedzin twórczych - pisarzy, fotografików, muzyków - stan wojenny to czas marazmu i poszukiwania nowych form wyrazu wymuszonych wydarzeniami politycznymi.

\section{Cultural life of Tri-City under martial law and... "post-war"}

The imposition of martial law in Poland was not without the influence on people of culture, many of them could not practice their profession due to the suspension of cultural institutions. After 13 December 1981, the community of actors in the whole country declared boycott of the media which evolved into the longest strike of the martial law period in Poland. Some of people of culture felt forced to go into exile, others engaged in underground actions of independent culture. Actors rejected their former role of propaganda tools and under martial law decided to become a conscious commentators of the reality.

In January 1982 in Warsaw the Committee of Independent Culture was established which supported various artistic exposition, theatre performances, and initiatives of artists in order to allow for a free circulation of arts. The Committee published a monthly entitled Przedświt (literary meaning dawn or daybreak). People of culture were also actively engaged in helping internees and their families, and assisted people needing spiritual help.

Following some patterns developed under the German occupation during WWII, a home theatre was revived, but only for a closed group of trusted audience, and for this reason the gap that opened up was fulfilled in the most spectacular way by the Roman Catholic Church. The Church became the foundation of actions, offered shelter, but also a space for artistic creativity. Martial law made churches full of people, not only the faithful, but also those who shared the spirit of independent thought. The role of the Church under martial law could not be overestimated both in the spiritual, and material sphere.

The flowering of independent culture in the Church would not have been possible without courageous and outstanding people, such as Dominican Sławomir Słoma, a sympathiser of the opposition movement and still remembered in Gdańsk with gratitude, mainly because he helped all who needed help. In time, the independent movement of artists grouped around the Church took on a mass character and was an unprecedented phenomenon in the Polish culture of the 1980s. Open-minded hierarchs, like many Polish people, followed the example of Pope John Paul II, enjoying the Pope's pilgrimages to Poland, for the message of the Holy Father was totally different from that of the artificial language of the People's Poland newspeak. For many artists of different media - writers, photographers, musicians - the period of martial law was the time of lethargy and of looking for new forms of expressions imposed by political developments.

\section{Bibliografia}

Boruta T., Pokolenie '80. Niezależne malarstwo młodych $w$ wystawienniczym ruchu przykościelnym, „Biuletyn IPN” 2011, nr 1-2, s. 29-38.

Fułek W., Stinzing-Wojnarowski S., Kurort w cieniu PRL-u. Sopot 1945-1989, Gdańsk 2007.

Grubka M., Stawek - duszpasterz studentów i artystów, fragmenty niepublikowanej pracy doktorskiej, 2006, w: Niepokora. Artyści i naukowcy o Solidarności 1980-1989, red.

S. Figlarowicz i in., Gdańsk 2006, s. 41-44. 
Grubka OP M., Działania władz państwowych i kościelnych wobec gdańskiego duszpasterza akademickiego o. Stawomira Stomy OP (1979-1985), w: Komunistyczny aparat represji wobec Polskiej Prowincji Dominikanów, red. M. Miławicki OP, M. Wenklar, Kraków 2015, s. 270-288.

Guzek Ł., Galeria jako zagadnienie artystyczne w sztuce konceptualnej, „Sztuka i Dokumentacja” 2012, nr 6, s. 123-130.

Kozieł A., Za chwile dalszy ciag programu... Telewizja Polska czterech dekad 1952-1989, Warszawa 2003.

Ligarski S., Polityka władz komunistycznych wobec twórców kultury w latach 1945-1989, w: Pokolenie '80. Niezależna twórczość młodych w latach 1980-1989, red. T. Boruta, Kraków 2010, s. 51-73.

Ligarski S., Ruzikowski T., Kultura niezależna, w: Pokolenie '80. Niezależna twórczość mtodych $w$ latach 1980-1989, red. T. Boruta, Kraków 2010, s. 69-77.

Małachowska E., Duszpasterstwa akademickie a kultura niezależna $w$ Kościele $w$ latach osiemdziesiatych, ze szczególnym uwzględnieniem Górnego Ślaska, „Biuletyn IPN” 2011, nr 1-2, s. 57-66.

Pick D., Ponad żelaznq kurtyna. Kontakty społeczne między PRL i RFN w okresie détente $i$ stanu wojennego, Warszawa 2016.

Przastek D., Scena bez kłamstw. Teatr w kościele po 13 grudnia 1981 roku, „Biuletyn IPN” 2011, nr 1-2, s. 48-56.

Przastek D., Środowisko teatru w okresie stanu wojennego, Warszawa 2005.

Ruciński A., Działalność Komitetu Kultury Niezależnej w latach 1982-1989, „Przegląd Prawniczy, Ekonomiczny i Społeczny” 2013, nr 4, s. 47-54.

Skiba K., Janiszewski J., Konnak P., Artyści, wariaci, anarchiści. Opowieść o gdańskiej alternatywie lat 80-tych, Warszawa 2011.

Skotarczak D., Obraz społeczeństwa PRL w komedii filmowej, Poznań 2004.

Zaremba P., Młodopolacy. Historia Ruchu Młodej Polski, Gdańsk 2000.

Biogram: Joanna Grey - absolwentka Wydziału Historycznego oraz Ekonomicznego Uniwersytetu Gdańskiego, manager kultury. Zajmuje się historią społeczną PRL, ze szczególnym uwzględnieniem codzienności i mentalności ludzi. Autorka pracy poświęconej życiu codziennemu w stanie wojennym na przykładzie Trójmiasta. E-mail: greyjoanna@gmail.com. 